\title{
A horse warrior's armament based on studies of the Przeworsk culture cemeteries from the Roman Period
}

\author{
Výzbroj bojovníků na koních na základě výzkumů \\ przeworských pohřebišt z doby ř́mské
}

- Emilia Smótka-Antkowiak* - 
or burials lacking weapons. On the other hand, the graves with spurs that were equipped with weapons, and which can probably be labelled as those of warriors, show a strong differentiation. Therefore, this analysis intends to explain the nature of such differentiation. Can they be considered as a sign of a specific hierarchy within the military structures of the Przeworsk culture? Or is it conditioned by the changing methods of fighting and the weapons in use? Another possibility may include other conditions affecting the diversity of the weapon set, such as local traditions, fashion or the richness of a particular community.

To answer the aforementioned questions, the author analysed 226 burial sites of the Przeworsk culture that were equipped with spurs (see Tab. 1 at the end of this article). Only compact sites with precise chronology were taken into account in the analysis, which means that the material base does not constitute all spur finds in the area of the Przeworsk culture, such as random finds or heavily damaged or looted burials. The author realizes that with the resignation of including imprecisely dated burials, she has omitted a significant amount of data, which distorts the image of the reality of that time. However, the author believes that with the inclusion of these, that in many cases it would be wrong to distort rather than improve the reliability of the results obtained.

The first part of the article focuses on the differences between the kit of the horse warriors and the foot warriors. The knowledge regarding the variability of weaponry equipment for the infantry (i.e. graves not equipped with spurs) was obtained from the above-mentioned works of B. Kontny. The source data provided there has been configured to extract and characterise groups of graves devoid of spurs. On the other hand, based on the source database obtained by the author, groups of gravesites with spurs were isolated. Both the analysed groups are compatible in terms of chronology, which enables a proper comparison of the results obtained. The second analysis concerns the diversification of the weapon sets within the burials containing spurs. The author then posed the question of whether the armour of the deceased rider was affected by the size of the community in which they lived and were buried. Are there any differences in the equipment of the deceased in the cemeteries with single burials of this type and those where more of them were discovered? Do the cemeteries with an increased number of spurs feature a hierarchy among a group of the buried horse warriors? The final chapter will deal with the variability of the weapons of the warriors depending on the particular community - the cemetery. By analysing the sets of weapons in the framework of cemeteries where there was a greater number of graves with spurs, the author will verify the existence, or lack of, of any local traditions and customs associated with equipping the deceased with spurs.

An obvious but important aspect is that the subject of the analyses are "weapon sets" and not the individual elements they are comprised of. The aim of the work is not to present the diversity of weapons and the diversification of the warrior's equipment. This is because only the entire set allows us to characterise or hierarchise the find. For similar reasons, the quantity or quality of the weapons will be less important from the point of view of these considerations than the element of the category of weaponry present in the grave. There are three main weapon categories found in the Przeworsk burials with spurs: swords, pole weapons and shields. The author assumes, after the works of B. Kontny, that the "sword" category is represented by the presence of either a sword itself and/or scabbard fittings. The "pole weapon" category is represented by the presence of a spear and/or a javelin head. Third, the presence of a shield boss, and/or a grip, and/or shield fittings represents the "shield" category. The Przeworsk burials also commonly comprise arrowheads, which prove the use of bows. ${ }^{3}$
The author is aware of the presence of a whole series of distortions of the actual historical image, resulting from the specifics of the archaeological sources studied, as previously indicated by other researchers (see Kontny 2003a, 113). These distortions result from the destruction of the historic material (the post-accession process or simply the rite of destroying weapons before burial) and the adoption of inappropriate research methods, etc. It should also be noted that all research related to sacrum is rife with a number of interpretational errors. Even at the level of the excavation and the description of the source material, one can have doubts about the relationship with the contemporary reality that is currently being discovered in the burial. Does this equipment testify to the deceased or rather to the community that buried them? It is commonly accepted that the type, quantity and quality of burial gifts are indicative of the role of the deceased during their life (Kontny 2003a, 113), hence the categorisation of "prince", "blacksmith" or "warrior" graves. The burial can be considered as a testimony to the relationship connecting the deceased with the rest of the community; it may also indicate respect for the deceased, and their social and property status. It is also impossible to deny such reasoning, which is also shared by the author of this article. However, it should be noted that the grave is a product of the community that buried the deceased and, indeed, also a form of testimony. It was the actual rite, adopted by the mourners, that determined what would be placed in the grave, as there may have been a selection procedure (for example, a ban on laying weapons and iron in graves in the Wielbark culture). It may have depended on the wealth of the people as to whether certain items could be excluded from use, or perhaps the property of the deceased was more useful to someone else, etc. The structure and economy of the society also depended on whether the deceased was equipped with their "personal" items. We do not know what the question of ownership looked like, or whether there was something that today we would call "private property". As B. Kontny wrote, for example, the weaponry could be distributed by the war chief and not be included in the grave to be used in the afterlife (Kontny 2003a, 113). Consciously, and sometimes unconsciously, we are exposed to mistakes made at each stage of research, which in effect distort or even falsify the results obtained. Nevertheless, according to the author, the broadest possible database, a reliable source selection and a detailed analysis should positively influence the resulting interpretations and minimise the margin of error.

\section{Diversification of weapon sets in burials with and without spurs}

At this point, the author focuses on the differences between the kit of the horse warriors and the foot soldiers. The knowledge about the variability of weaponry equipment for the infantry (i.e. graves not equipped with spurs) was obtained from the above-mentioned works of B. Kontny. The source data provided by them has been configured to extract and characterise groups of graves devoid of spurs. On the other hand, based on the source database obtained by the author, groups of gravesites with spurs were isolated. Both of the analysed groups are compatible in terms of chronology, which will enable a full comparison of the results obtained.

The following decision is the result of categorising the 226 burial sites containing spurs into the above-mentioned phases: 45 graves from phase $\mathrm{B} 1,{ }^{4} 16$ graves from phase $\mathrm{B} 2 \mathrm{a}$, 52 graves from phase $\mathrm{B} 2 \mathrm{~b}, 73$ graves from phase $\mathrm{B} 2 / \mathrm{C} 1,37$ graves from late $\mathrm{Cla}-\mathrm{C} 1 \mathrm{~b}$ phase and only 3 graves from the $\mathrm{C} 2-\mathrm{D}$ phases. Graph 1 shows the percentage of graves with spurs analysed in this work in the group of graves with weapons analysed by Kontny. 


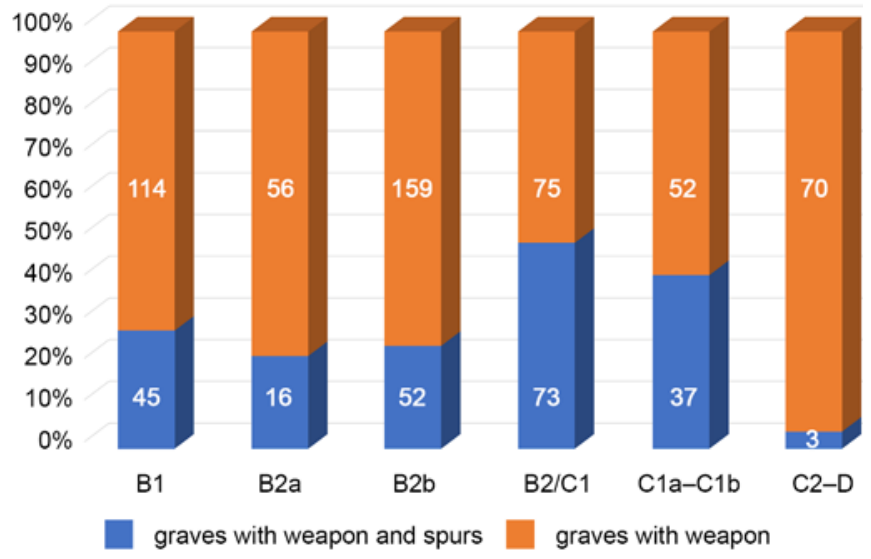

Graph 1. Percentage share of the analysed graves with spurs in the group of graves with weapons analysed by B. Kontny (Kontny 2001; 2003a).

Graf 1. Procentní podíl analyzovaných hrobů s ostruhami v hrobech bojovníků podle B. Kontny (2002b; 2003a).

The presented data confirms the known dependence on the gradual increase in the occurrence of spurs in graves with weapons from the beginning of the Early Roman Period to the B2/C1 phase, and then their decrease, leading to them almost disappearing in the C2-D phases of the Late Roman Period (Kontny 2001; 2003a).

\subsection{B1 phase}

The analysis of 45 burial sites from the $\mathrm{B} 1$ phase enabled to distinguish nine sets of weapons that accompanied the spurs in the graves: 1. Pole weapon + shield, 2. Pole weapon, 3. Shield, 4. Sword + pole weapon + shield, 5. Sword, 6. Sword + pole weapon, 7. Sword + shield, 8. Sword + pole weapon + shield + bow, 9. No weapon. ${ }^{5}$ The results presented in the table indicate a clear differentiation in the percentage of weapon sets in graves with and without spurs (Graph 2). The biggest discrepancy is noticeable in the category of "pole weapons". While the weapon model dominates graves with weapons but lacking spurs, a combination with spurs is relatively rare (4.4\%). A warrior equipped with only a weapon that corresponds to arming standard infantry - the foot soldier (Kontny 2003a, 121) - is one of the most frequently found (Kontny 2002; 2003a). However, the position of the warrior changes drastically when spurs are added to their equipment, consequently indicating the existence of a mount. However, as the

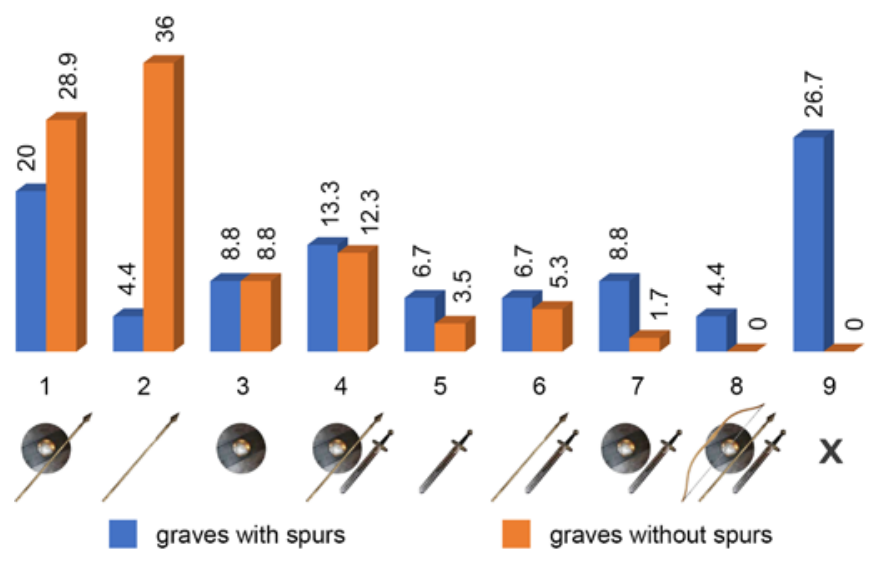

Graph 2. Diversification of weapon sets in burials of the Przeworsk culture dated to the B1 phase.

Graf 2. Diverzifikace výzbroje v hrobech przeworské kultury datovaných do stupně B1. analysis shows, such a set was not particularly prevalent at the beginning of the Common Era.

One of the most common sets of weaponry in graves with and without spurs during the entire of the Roman Period is the combination of "a pole weapon + shield" (see Fig. 1, Kamieńczyk grave 292). Every fifth grave (20\%) among the graves with spurs comprises such a set, and it does not differ significantly from the popularity of such gear among common infantry (28.9\%).

Shield elements are found in both categories of burials at an identical rate: $8.8 \%$. A set consisting solely of a shield, which is only a defensive weapon, does not appear to correspond to the actual weaponry of the contemporary warrior. Such a warrior would be deprived of an offensive weapon to attack their opponent with. Therefore, several interpretations can explain the occurrence of a sole shield in a grave. These refer to the symbolic meaning of the shield representing the entirety of their weaponry (Peschel 1991, 137; Schultze 1991, 177), or an element of apotropaic importance - protecting the deceased (Kontny 2003a, 121). There is also the possibility that the burials equipped with shields as the only element of weaponry were those of the lowest-class warriors as far as the military hierarchy was concerned (Peschel 1991, 131-141) although this interpretation should be excluded in the case of burials equipped with shields and spurs.

In the graves with both weapons and spurs, and those that do not contain elements of equestrian gear, the wealthiest of sets consisting of a sword, a pole weapon and a shield, are present on a similar level. In graves with spurs, the set occurred at a rate of $13.3 \%$ (see Fig. 2, Domaradzice grave 1), while it was $12.3 \%$ in those without spurs. However, in general, "richer" weapon sets (No. 4-7), i.e. those containing swords, clearly appear more often accompanied by spurs than without them: with spurs, they constitute $39.9 \%$ of the graves and, in burials not equipped with spurs, then only $22.8 \%$. The sword, according to Godlowski's assumptions, belonged to the most valuable elements of weaponry, while the spurs were only found in, above all, the graves of rich, and even the wealthiest (Godlowski 1960, 40-41, 50-53, 82). Considering the practical aspect of the use of a sword in horse fighting, it does not appear to have had a decisive impact on the combination of these weapons. The analysis conducted by Kontny shows that in the graves containing equestrian gear, the frequently found long and short swords, would not be useful in horse fighting. It is also worth mentioning that according to Bartosz Kontny, during the Roman Period, people fought on foot and used the horse as a form of transport to reach and possibly retreat from the battlefield (cf. Kontny 2001, 102-106; Kontny 2003a, 119; Kontny 2003b, 254-255). Therefore, the relationship of the swords and elements of equestrian gear should be explained by prestige/wealth considerations because both these elements of arms can be considered as determinants of the high social position of the deceased in question (Godłowski 1960).

Every fourth grave with spurs from phase B1 was devoid of weapons (26.7\%). However, a high percentage of these graves were largely influenced by predominately analysing the burials in cemeteries in the Nidzica group area (Gródki - 3 graves, Niedanowo - 2 graves (Ziemlińska-Odojowa 1999), Modla 2 graves), which was characterised by a different funeral rite that prohibited placing weapons in graves (Okulicz 1983). Among the graves with spurs from the beginning of the Roman Period, there is also a noticeable greater variation in weapon sets than in the burials without spurs. B. Kontny explained this by the influence of the new cultural trends flowing from the Roman Empire, which first reached the elite, and presumably, is why among the "wealthy" burials we can observe an individualised approach to equipping the deceased with arms (Kontny 2003a, 122). 


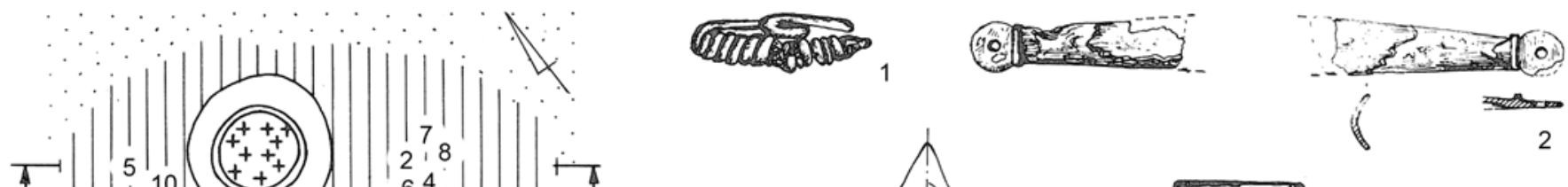

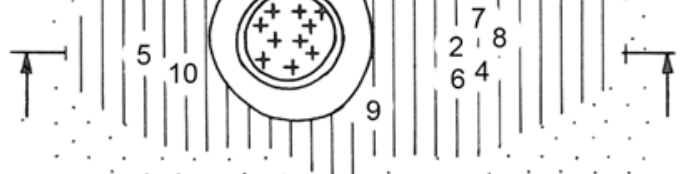

$-35$
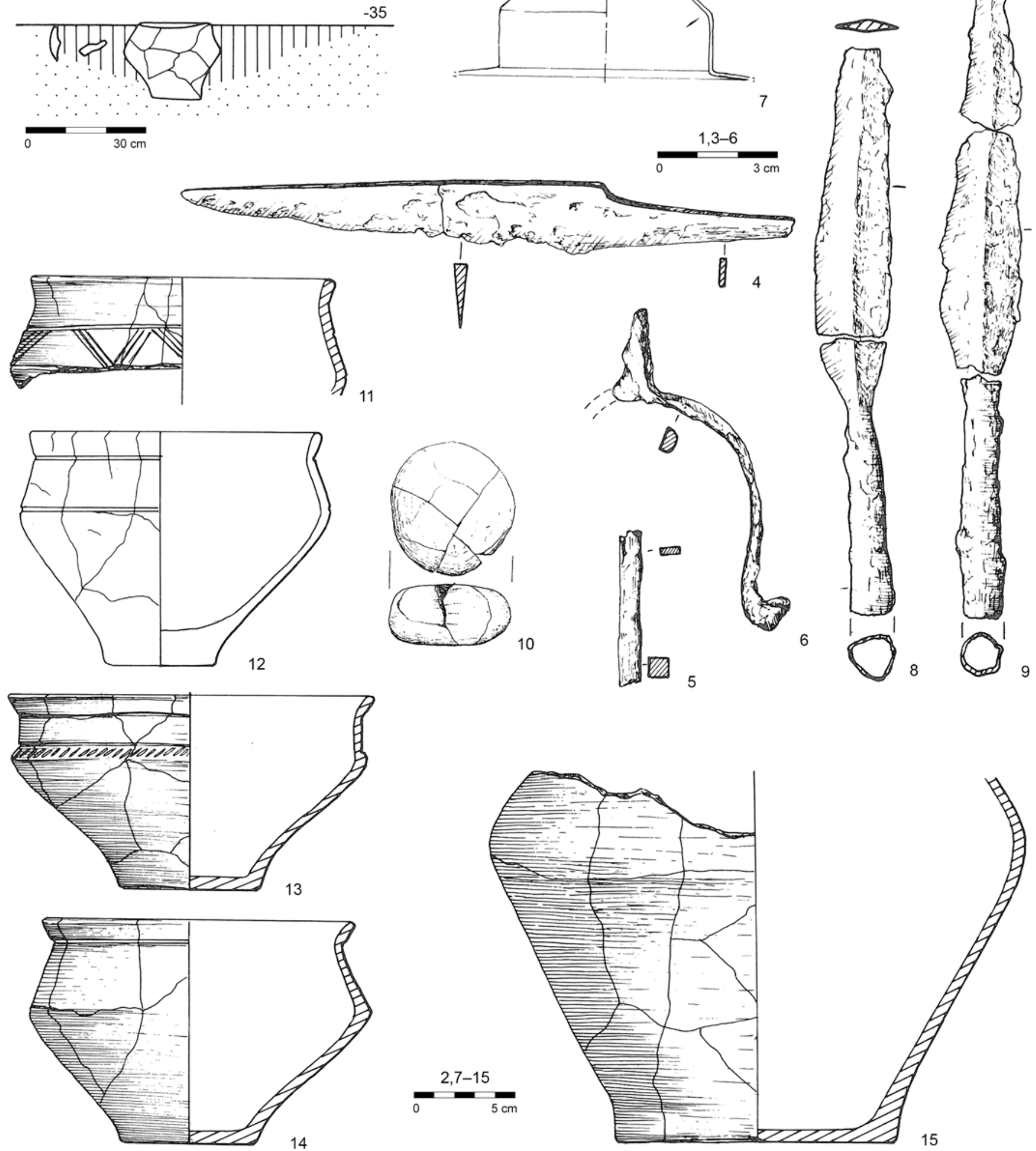

Fig. 1. Kamieńczyk, grave 292. Pottery and bronze (1, 3), iron (2, 4-9) and stone (10) items from the grave (after Dąbrowska 1997, 265, Tabl. CXXXV).

Obr. 1. Kamieńczyk, hrob 292. Keramika, bronzové $(1,3)$, železné $(2,4-9)$ a kamenné (10) předměty z hrobu (podle Dąbrowska 1997, 265, Tabl. CXXXV). 


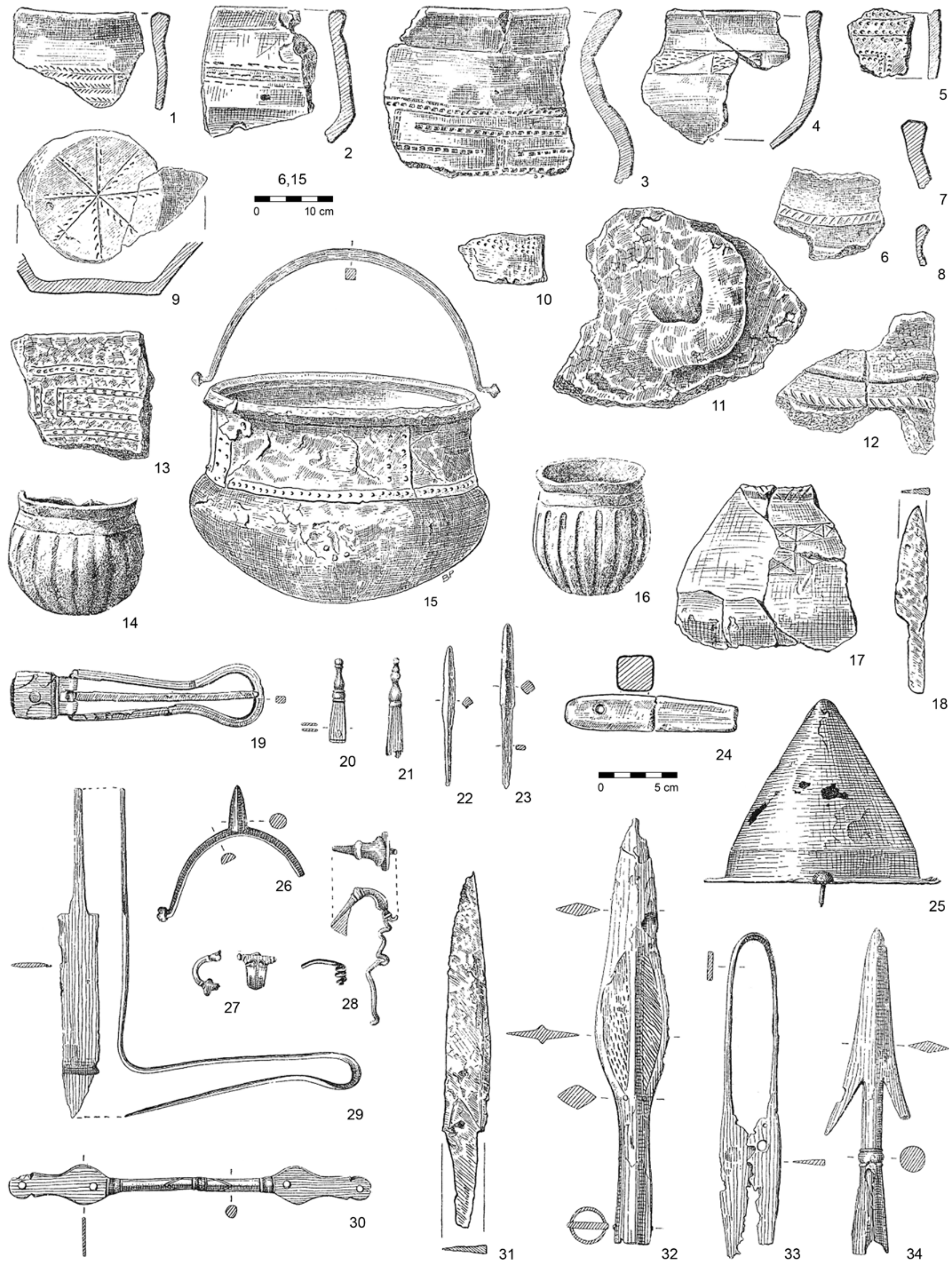

Fig. 2. Domaradzice, grave 1. Brown cauldron (15), pottery and bronze, iron and stone items from grave No. 1 (after Kostrzewski 1939, 156, Fig. 3, 158, Fig. 4).

Obr. 2. Domaradzice, hrob 1. Bronzový kotel (15), keramika a bronzové, železné a kamenné předměty z hrobu (podle Kostrzewski 1939, 156, Fig. 3, 158, Fig. 4). 


\subsection{B2a phase}

The analysis of 16 burial sites from the B2a phase enabled to distinguish between five sets of weapons that accompanied spurs in the graves: 1 . Pole weapon + shield $(13 \%), 2$. Shield (6.2\%), 3. Sword + pole weapon + shield (31.3\%), 4. Sword (6.2\%) and 5 . No weapon (43.7\%). The results obtained based on the analysis indicate a specific weapon standardisation. However, these standards are different for the group of graves containing spurs in relation to burials deprived of this category of burial gift (Graph 3). When reading the results of this analysis, it should be taken into account that a narrow source base (16 graves) may not be sufficiently representative for obtaining reliable results. The reason for the separation of such a small number of graves with spurs for this chronological section is due to the decline in the role of equestrian gear as part of a burial gift in phase B2 (Kontny 2001, Graph 10-11; 2003a, 124).

The "rich" set of weapons (see Fig. 3, Kamieńczyk grave 320); consisting of a sword, a pole weapon and a shield (31.3\%) dominates the inventory of graves containing spurs. This result is in direct contrast with the data obtained based on a group of graves that do not contain spurs, where the combination was only found in $7.1 \%$ of burials, while the combined ratio of "wealthy" graves i.e. equipped with swords - dropped significantly compared to the previous phase and amounted to only $14.3 \% .{ }^{6}$ A completely different situation can be seen in the example of graves without spurs: $46.4 \%$ feature the set of a pole weapon + a shield (No. 1), which constitutes only $13 \%$ in the graves with spurs. The results of the above analysis may indicate a specific division, highlighting the borders between the foot soldiers and the horse warriors of the Przeworsk culture. Perhaps a standard was created during this period - only equipping a strictly defined group of high-ranking warriors with "rich" sets of weapons (including spurs and a sword). Similarly, the appearance of a certain standardization can be seen as the uniform equipment of a lower-ranking foot soldier consisting of a weapon and/or shield.

During this period, a significant increase in the number of graves with spurs but not equipped with weapons can be observed, which accounts for almost half of these burials (43.7\%). However, this image, as in the previously analysed phase, is strongly distorted by the burials from the so-called Nidzica group (Niedanowo, Modla), which account for $37.5 \%$ of the burials included in the analysis.

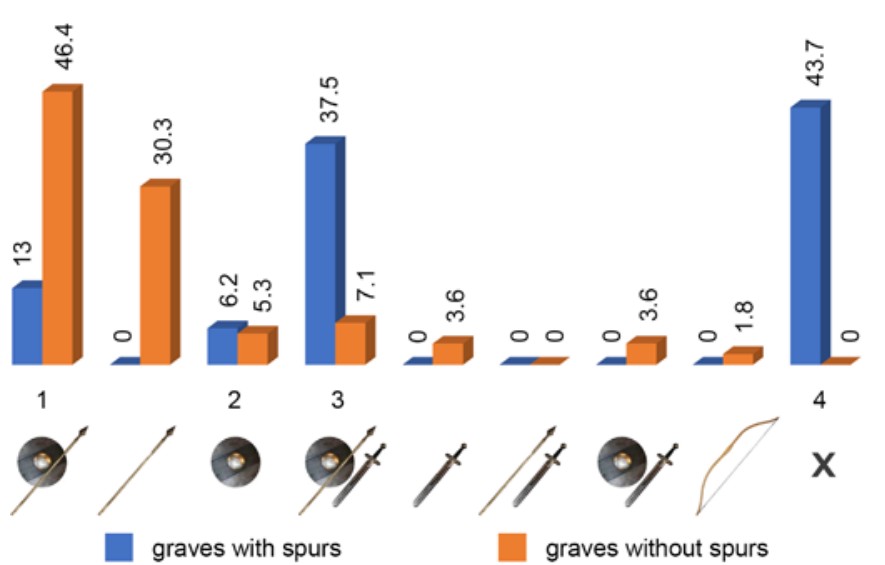

Graph 3. Diversification of weapon sets in burials of the Przeworsk culture dated to the B2a phase.

Graf 3. Diverzifikace výzbroje $v$ hrobech przeworské kultury datovaných do fáze B2a.

\subsection{B2b phase}

For the later phase of B2, we managed to obtain a more representative group of graves with spurs consisting of 52 graves, which is much more representative in relation to the previous phase (B2a). On this basis, nine sets of weapons accompanying spurs were distinguished (Graph 4): 1. Pole weapon + shield (26.9\%), 2. Pole weapon (21.1\%), 3. Shield (3.8\%), 4. Sword + pole weapon + shield (25\%), 5. Sword (1.9\%), 6. Sword + shield (1.9\%), 7. Bow (1.9\%), 8. Polearm + shield + bow (1.9\%), 9. No weapon (15.4\%). In the graves with spurs, as in the previous phase, then to a lesser extent, the "rich" weapon sets - containing the sword - dominate: a total of $28.8 \%$ of the burials. The graves not equipped with elements of equestrian gear featured the "rich" set only $6.3 \%$ of the time.

Based on the analysis, it can also be noted that the standards for the equipment of graves with weapons that do not contain spurs from phases Bla and B2b appear to be remarkably similar. However, the real differences are mainly noticeable in the burials with spurs. In the later section of the B2 phase, the percentage of the sets containing pole weapons and shields (26.9\%) is increased together with the reappearance of pole weapons in the company of spurs (21.1\%). The emergence of a fairly strong class of horse warriors equipped with a weapon and/or a shield (see Fig. 4, Cieblowice Duże, grave 58) next to the still-dominant group of warriors equipped with "rich" sets of weapons, can be considered as a sign of a hierarchy in the ranks of horse warriors. The author thus concludes, with a degree of uncertainty, a possible division of horse warrior classes found in the B2b period on at least two levels: 1. The so-called "commander" - graves with "wealthy" equipment, 2. lower-ranking horse warrior - graves with pole weapons and/or shield. It should be noted, however, that this is only one of the possible interpretations because some other options should still be considered, including those taking into account the "symbolic" meaning of the weapon placed in the grave.

In the $\mathrm{B} 2 \mathrm{~b}$ phase, the share of graves with spurs not equipped with weapons dropped significantly, although it remained at a relatively high level (15.4\%). In contrast to the previous chronological sections, a high percentage of graves with weapons cannot be explained this time by disturbances resulting from the inclusion of graves from the area of the so-called Nidzica group (where it was prohibited to place weapons in the graves), as burials with no weapons come from the whole area of the Przeworsk culture.
Graph 4. Diversification of weapon sets in burials of the Przeworsk culture dated to the B2b phase.

Graf 4. Diverzifikace výzbroje v hrobech przeworské kultury datovaných do fáze B2b. 


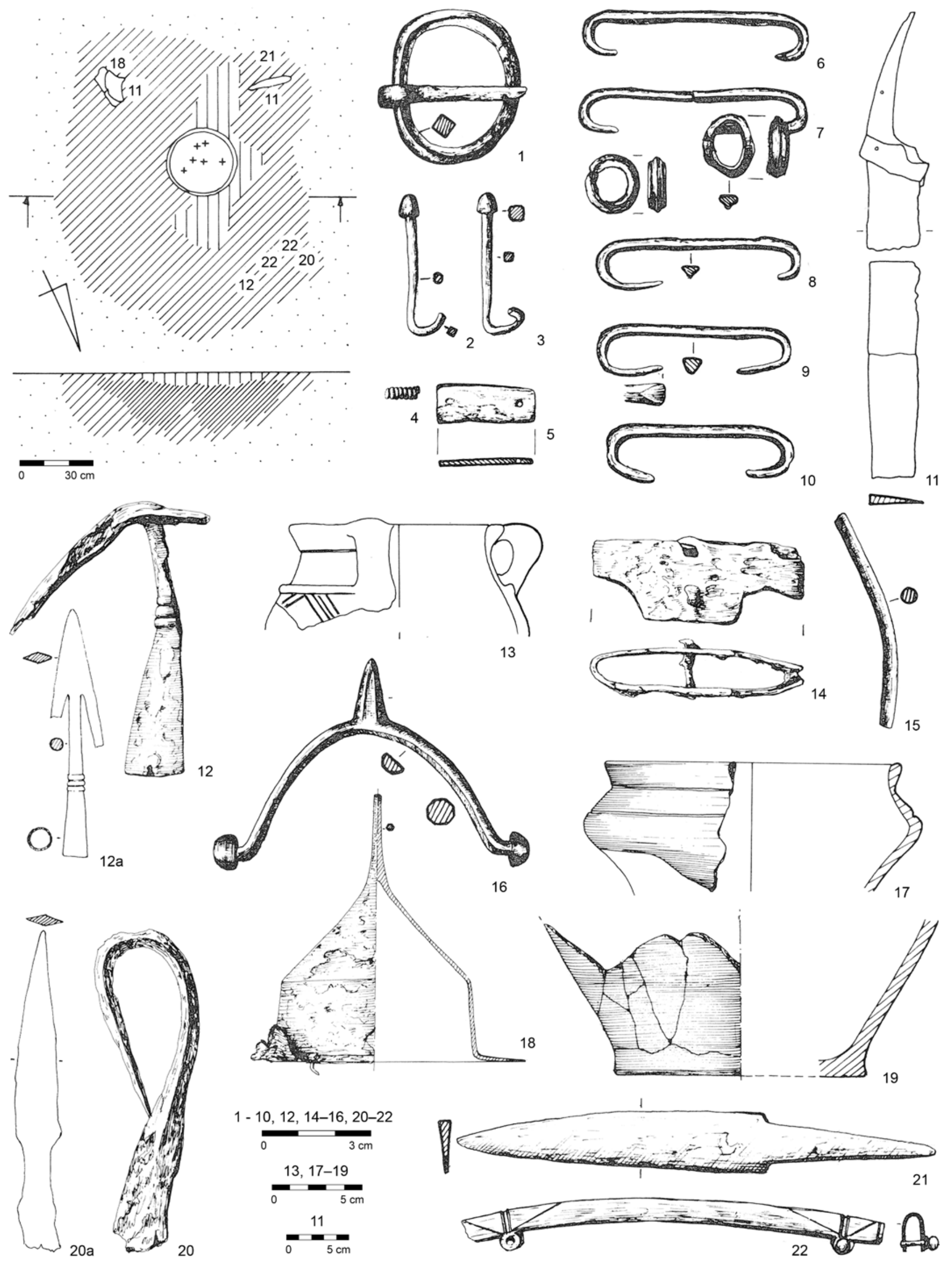

Fig. 3. Kamieńczyk, grave 320. Pottery, bronze (4, 22,) and iron items from the grave (after Dąbrowska 1997, 275, Tabl. CXLV).

Obr. 3. Kamieńczyk, hrob 320. Keramika, bronzové (4, 22) a železné předměty z hrobu (podle Dąbrowska 1997, 275, Tabl. CXLV). 


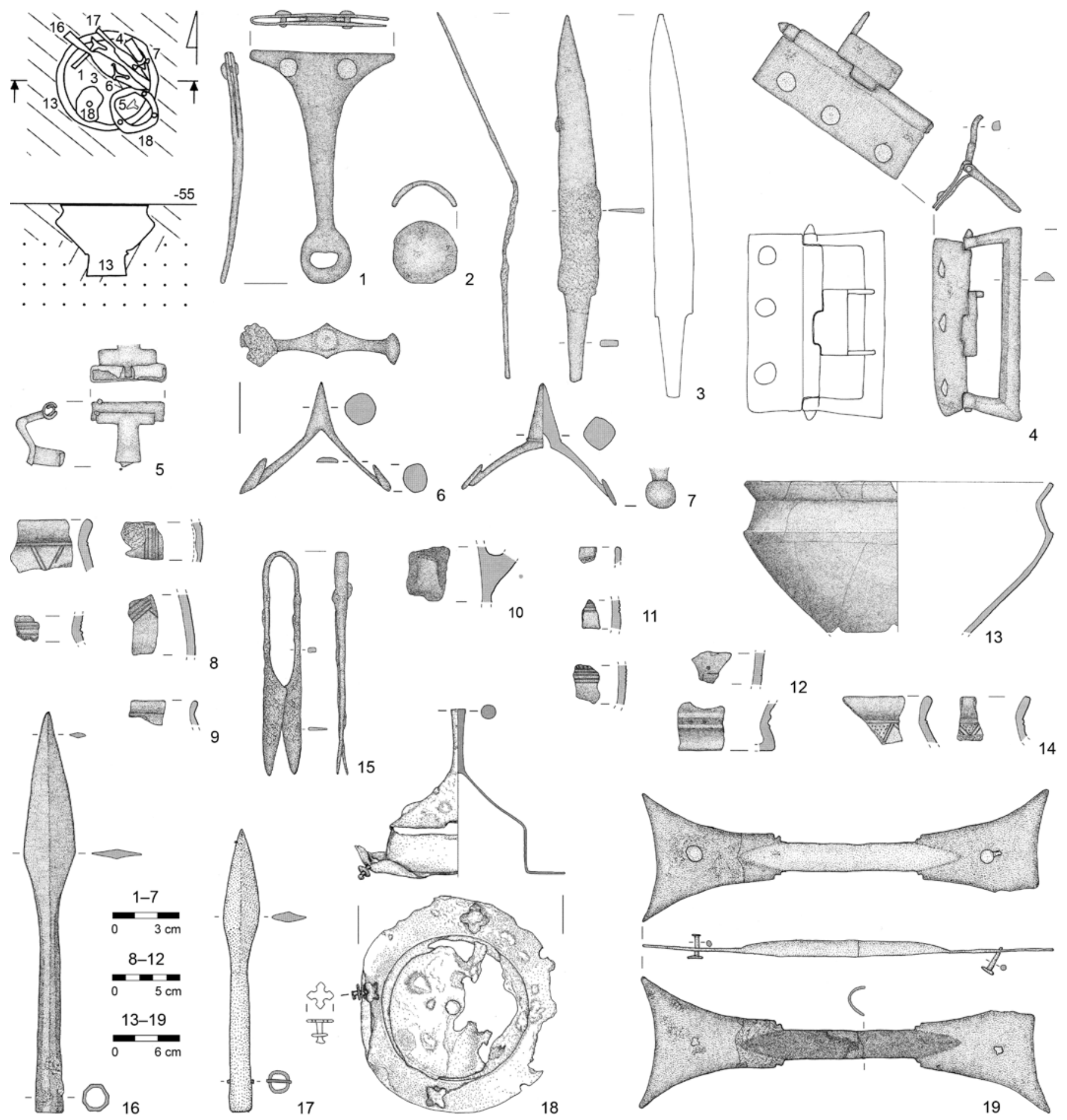

Fig. 4. Ciebłowice Duże, grave 58. Pottery and iron items from the grave (after Dzięgielewska, Kulczyńska 2008, 154-156, Tabl. XLVI).

Obr. 4. Ciebłowice Duże, hrob 58. Keramika a železné předměty z hrobu (podle Dzięgielewska, Kulczyńska 2008, 154-156, Tabl. XLVI).

It appears that this time, placing a spur in the grave, in which none of the other items of equipment can be found, could have a symbolic character. A spur placed into a grave could symbolise the high social status of the deceased, belonging to a specific social group or a specific family. The presence of spurs could also be the result of inheritance, etc. There are many interpretive possibilities although they will not be discussed in detail in this work.

\subsection{B2/C1 phase}

The largest group, 73 graves with spurs, are burials dated to the $\mathrm{B} 2 / \mathrm{C} 1$ phase and the beginning of the Cla phase. From their analysis, the author distinguished nine sets of weapons that accompanied spurs (Graph 5): 1. Pole weapon + shield (24.6\%), 2. Pole weapon (8.2\%), 3. Shield (5.5\%), 4. Sword + pole weapon + shield (19.2\%), 5. Sword + pole weapon (4.1\%), 6. Sword + 


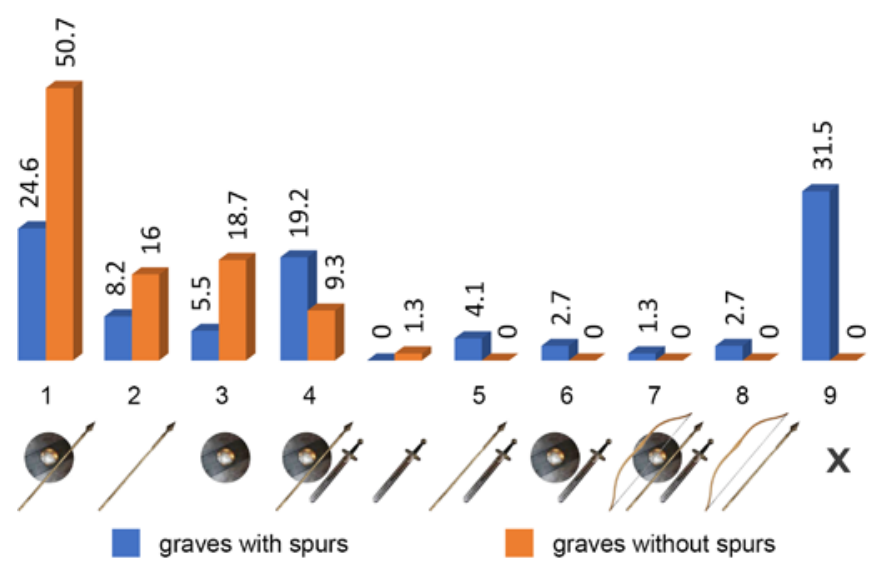

Graph 5. Diversification of weapon sets in burials of the Przeworsk culture dated to the $\mathrm{B} 2 / \mathrm{C} 1$ phase.

Graf 5. Diverzifikace výzbroje $v$ hrobech przeworské kultury datovaných do fáze B2/C1.

shield, (2.7\%), 7. Sword + pole weapon + shield + bow (1.3\%), 8. Pole weapon + bow (2.7\%), 9. No weapon (31.5\%).

The biggest change in the equipment in the graves with spurs in relation to the previous period is an almost twofold increase in the frequency of the graves not equipped with any weapons at the expense of graves that are equipped with them (from $15.4 \%$ in phase $\mathrm{B} 2 \mathrm{~b}$ to $31.5 \%$ in $\mathrm{B} 2 / \mathrm{C} 1$ ). The proportions of the weapon combinations remain similar as in the $\mathrm{B} 2 \mathrm{~b}$ phase. The "rich" weaponry sets still dominate, i.e. those containing swords ( $27.3 \%$ in total). A clear drop is noticeable in the range of graves containing weapons with the first combination (Pole weapon + shield -24.6\%), and above all, in set No. 2 (Pole weapon-8.2\%). Graves with spurs but with no weapons (see Fig. 5, Opatów grave 879 ), which account for $31.5 \%$ of all of the analysed burials in this phase, come from various areas of the Przeworsk culture. However, a few cemeteries comprise concentrations of this type of grave: Opatów (11 graves), Wymysłowo (3 graves; Jasnosz 1952), Młodzikowo (2 graves; Dymaczewski 1958). On this basis, it can be concluded that an increase in the "symbolic" meaning of the spurs in the funeral rite (the most probable interpretation of their presence in burials without weapons) concerned only selected local communities, not the general population of the Przeworsk culture.

The number of graves with spurs equipped with shields oscillates around 5.5\%, at the same level as in the previous phases. However, among the graves without any elements of equestrian gear, a marked increase in the prominence of burials equipped with shields as the only weapon is visible (from $3.8 \%$ in the B2b phase to $18.7 \%$ in B2/C1). B. Kontny explains the increased prevalence of graves with metal shield fittings observed in the discussed period, as a probable reaction to the development of longer and better chopping swords. This was to counteract the emerging cutting focus of the more effective new sword designs (Kontny 2003a, 136).

\subsection{C1a-C1b phase}

The analysis included 37 burial complexes from the late $\mathrm{Cla}$ phase and the $\mathrm{Clb}$ phase, which enabled to distinguish between eight sets of weapons discovered in the burials of the Przeworsk culture containing spurs. These sets are presented as follows: 1. Pole weapon + shield (18.9\%), 2. Pole weapon (8.1\%), 3. Shield (8.1\%), 4. Sword + pole weapon + shield $(24.3 \%)$, 5 . Sword + pole weapon (10.8\%), 6. Sword + shield $(5.4 \%), 7$. Pole weapon + bow $(2.7 \%)$,
8. No weapon (21.6\%). The data presented in the Graph 6 shows that the beginning of the Late Roman Period brought noticeable changes in the equipment found in graves containing spurs. The proportions of the first three weapon combinations did not change significantly and remained at a similar level: 1, 2 and 3. However, a significant change is observed in the "rich" graves (containing swords, among other items), which in the current phase constitute as much as $40.5 \%$ of the burials containing spurs. This increase was at the expense of a decrease in the proportion of graves not equipped with any weapons, which constitute $21.6 \%$.

Among the "rich" sets of weapons, the number of graves equipped with spurs, a sword and a pole weapon (an increase from $4.1 \%$ to $10.8 \%$ ), as well as graves with spurs, a sword and a shield (an increase from $2.7 \%$ to $5.4 \%$ ), grew in numbers in relation to the previous phase. An increase (from 19.2\% to $24.3 \%$ ) in the prevalence of graves with full equipment was also observed, which consisted of a sword, a pole weapon and a shield. In the current chronological phase, as in the previous ones, no graves with spurs and a sword were registered. It appears that the weapons found in the above burials could correspond to the actual equipment of a horse warrior, as demonstrated by the fact that this phase featured double-edged swords of significant lengths (Biborski 1978, 104-105). The analysis by B. Kontny shows that the finds coinciding with elements of equestrian gear were usually of the longer variety while shorter forms were significantly rarer (Kontny 2002, 105). The above conclusions suggest the possibility of using swords in horse-fighting while still stressing the main role of horses as a form of transport to and from the battlefield.

To conclude, the analysis showed an increase in the complexity of weapon sets found in the graves of riders in the period corresponding to the late section of the $\mathrm{Cla}$ and $\mathrm{Clb}$ phases. It is worth noting that such changes were not observed based on the burials of infantry, where sets of weapons and their proportions remained almost unchanged compared to the previous period - B1/C1.

In his works, B. Kontny points out the diversity of the warriors' kit at the beginning of the Late Roman Period, indicated by, among other elements, the changes in the funeral rites ${ }^{7}$ and the ways of fighting, as a consequence of direct contact with the Roman army and weaponry (Kontny 2003a, 116). However, these theories apply to all the warriors, as this was how the analysis was conducted. From the observations made in this work, it appears that these assumptions mainly apply to horse warriors/

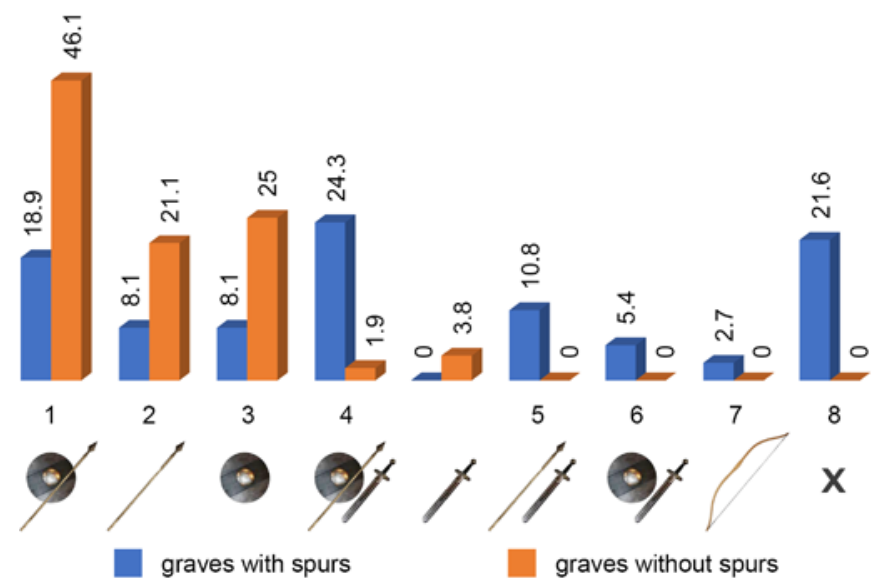

Graph 6. Diversification of weapon sets in burials of the Przeworsk culture dated to the $\mathrm{C} 1 \mathrm{a}-\mathrm{C} 1 \mathrm{~b}$ phase.

Graf 6. Diverzifikace výzbroje v hrobech przeworské kultury datovaných do fází C1a-C1b. 
those buried with spurs. Is it possible that the contacts with the Roman army and weaponry during the Marcomannic Wars would primarily influence only the class of the horse warriors? This possibility seems to have a logical justification in the huge distances that the Przeworsk fighters were forced to travel to fights on the borders. It would have been impossible without the help of a mount. In addition, issues remain, such as the prestige associated with participation in similar expeditions; perhaps only the most outstanding or highest-ranking warriors were selected, as well as pragmatic problems, such as the costs of arming or equipping a warrior, supporting their family during their absence, etc.
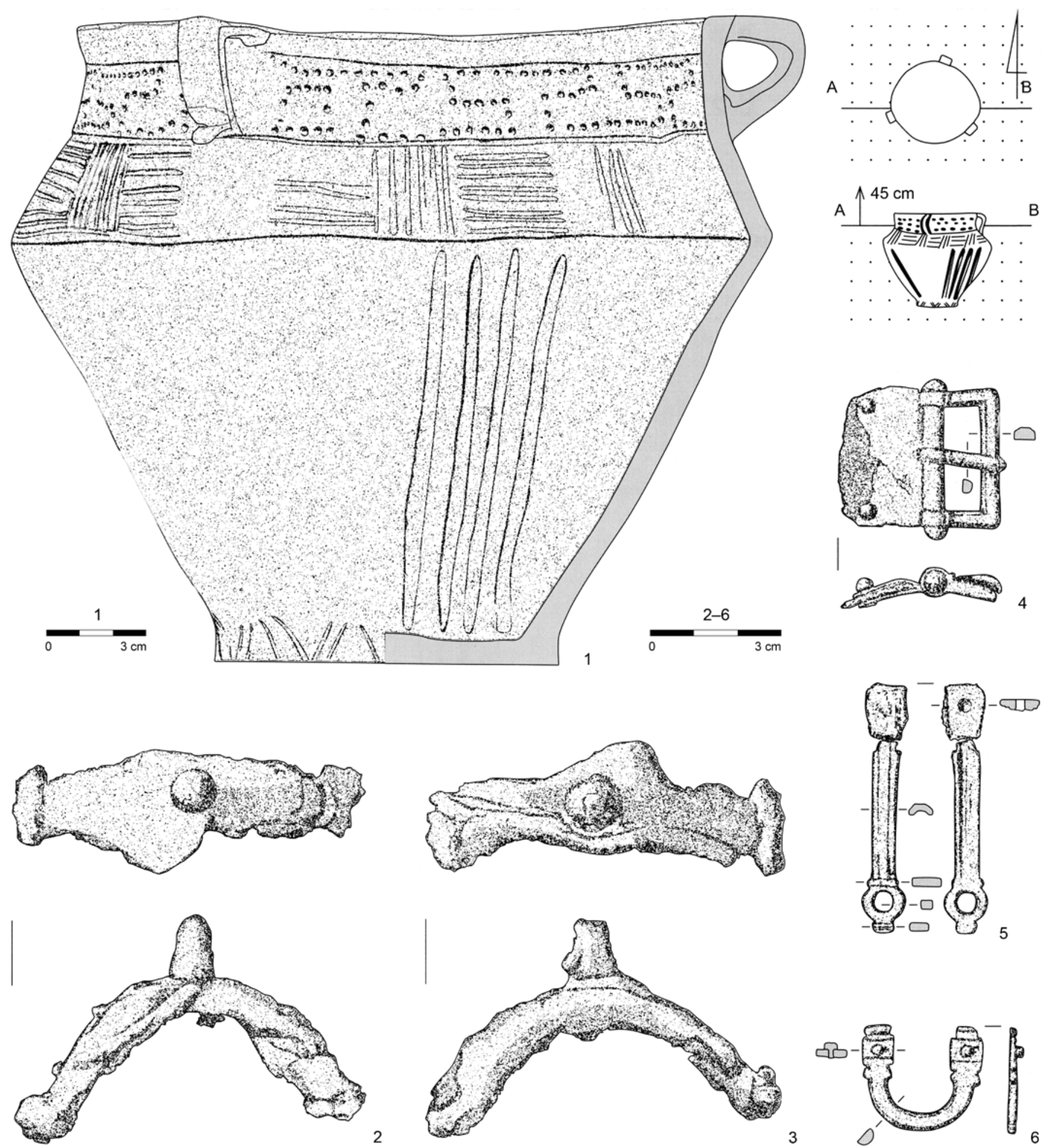

Fig. 5. Opatów, grave 879. Pottery, iron (2-3) and bronze (4-6) items from the grave (after Madyda-Legutko et al. 2011, Tafeln 315, Tabl. CCCXIII).

Obr. 5. Opatów, hrob 879. Keramika, železné (2, 3) a bronzové (4-6) předměty z hrobu (podle Madyda-Legutko et al. 2011, Tafeln 315, Tabl. CCCXIII). 


\subsection{C2-D phase}

As part of the last of the analysed chronological periods, there were only three burials with spurs. The number of graves with weapons (70 in total) also significantly fell. These changes were caused by the developments in the funeral rites that had already started in the C1b phase, which were expressed in the almost complete disappearance of urn graves, which were replaced by the spread of graves without urns. During this period, the deceased began to be placed in layered cemeteries, the socalled Dobrodzien type, which featured layers of burials without separate burial complexes (Szydłowski 1974, 15-16, 38-42, 99-100; Szydlowski 1977, 74-83; Kontny 2002, 113). The changes in the form of burials were accompanied by a significant reduction in the quantity of burial equipment (Godlowski 1985, 91; Szydłowski 1977, 76; Kontny 2002, 111-113). A smaller number of graves with weapons may have been caused not only by the changes in the funeral rites but also the migration of warriors from their native areas and their expansion to the western borders of the Roman Empire. The migrations of barbarians dating from the middle of the third century CE constituted not only the peoples of the borderland areas of the Rhine and the Danube but also the tribes inhabiting distant regions of Central Europe, and even Scandinavia (Kolendo 1997, 15; Kontny 2002, 113). The low number of horse warrior burials recorded in the period in question makes it impossible to obtain a comprehensive picture of the rider in the latter part of the Late Roman Period.

\section{Diversification of weapon sets within the group of the buried equipped with spurs}

The above analyses showed, on the one hand, the significant differences in the equipment of the deceased foot soldiers and horse warriors, and on the other hand, the disparities in the weapon sets within the horse rider class. ${ }^{8}$ In the course of her research on the subject of spurs, the author noticed that the diversity of weapon sets and grave equipment accompanying spurs changed not only chronologically but also geographically. The latter can be understood as parts of the Przeworsk cultural area influence, e.g. Nidzica group, the eastern zone of the Przeworsk Culture (Andrzejowski 2001) or the Greater Poland and Kuyavia cultural border (Machajewski 1980), as well as "territory" in a more local context - strictly related to a given cemetery. Individual barbarian communities, which testify to the Przeworsk burial grounds recently discovered by archaeologists, were significantly different from each other. These differences are visible in the occurrence of local traditions, in the degree of wealth (e.g. cemeteries located on trade routes are usually richer than those located in their periphery) or the characteristics of a given community (e.g. the cemetery in Wesólki, due to the disproportionately large amount of weaponry found therein, is often called the cemetery of a "warrior pack"), etc. The author posed the question: To what effect did the community in which the deceased rider lived influence how they lived, and thus, how they were buried? Is it possible to refer to a social class of "horse warriors" in a given community, or only about the symbolic aspect of the spurs that were found in the graves, etc.?

To refine the knowledge of the context of the presence of spurs in the Przeworsk community, the author carried out an analysis on two subsequent levels. First, she investigated the possible differences in the equipment of warriors buried in cemeteries, where there were single graves with spurs $(<2)$ in relation to those where more of these were recorded $(>2)$. A larger number of graves with spurs is usually recorded in large, longerused cemeteries. The development of communities associated with these necropolises was conditioned mostly by nearby trade

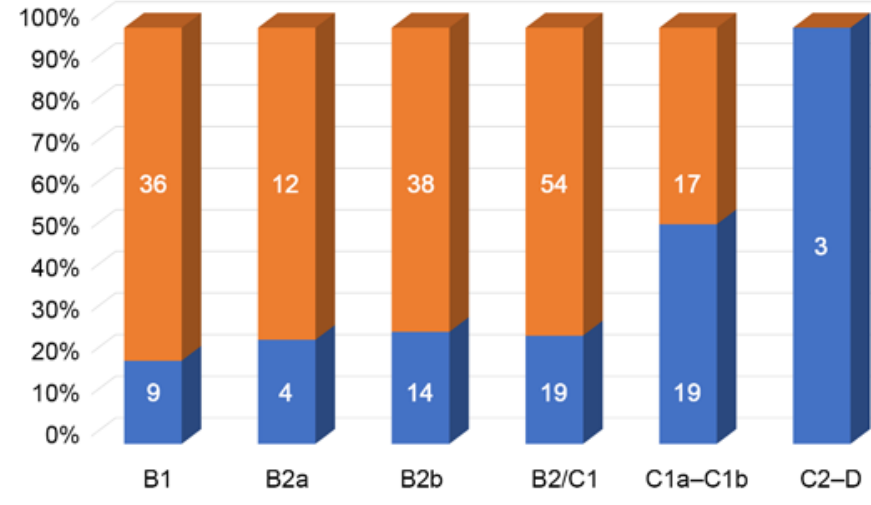

$<2$ graves with spurs in cemeteries

$>2$ graves with spurs in cemeteries

Graph 7. Proportion of cemeteries with single graves of horse riders and cemeteries with multiple graves.

Graf 7. Zastoupení ostruh na pohřebištích s jednotlivými hroby bojovníků na koních a na pohřebištích s více hroby.

routes and a thriving economy, which became the cause of maintaining intra and intercultural contacts, including the provinces of the Roman Empire. Among such communities, one can usually register a strongly represented class of warriors including horse riders. It is obvious that the degree of militarisation was different for each of the social groups; for example, relatively few weapons were discovered in the Przeworsk site in Karczyn-Witowy (Bednarczyk, Romańska 2015, 58-60), whereas, disproportionately, many burials with elements of weapons were recorded in the cemeteries of Lachmirowice (Zielonka 1951) and Wesółki (Dąbrowska, Dąbrowski 1967). Nevertheless, each case provides the opportunity to observe the relationships within the group of the deceased buried with spurs, which is the purpose of this analysis. The findings of spurs from large cemeteries and individual finds of burials equipped with spurs were contrasted in direct opposition. The latter were mostly graves from small peripheral cemeteries connected with communities of lesser economic importance.

\subsection{Diversification of weapon sets in cemeteries with single and multiple graves of horse riders}

Most of the burials with spurs (69\%) dated to the Roman Period, were discovered in cemeteries with other spurs finds. Only $30 \%$ of spur finds come from cemeteries where one, possibly two, burials equipped with this element of equestrian gear has been discovered. The proportion of each group of burials is shown in the Graph 7 and subsequently reveals that at the beginning of the Common Era as many as $80 \%$ of the dead buried with spurs had graves among larger communities, as evidenced by such large cemeteries as Ciecierzyn (Martyniak et al. 1997), Domaradzice (Kostrzewski 1954), Kamieńczyk, Modła (Grzymkowski 1986; 1996) and Oblin (Czarnecka 2007). In subsequent phases, the number of cemeteries containing single burials with spurs gradually increased. However, in the Early Roman Period, spurs were most common as individual finds in cemeteries, which was probably caused by the aforementioned changes in the funeral rites and the decrease in the number of graves with weapons in general.

\subsubsection{B1 phase}

Burials with spurs dated to the very beginning of the Roman Period mostly originate from large cemeteries, where more were discovered ( $>2$ ), i.e. in 36 out of the 45 graves dated to phase B1. 


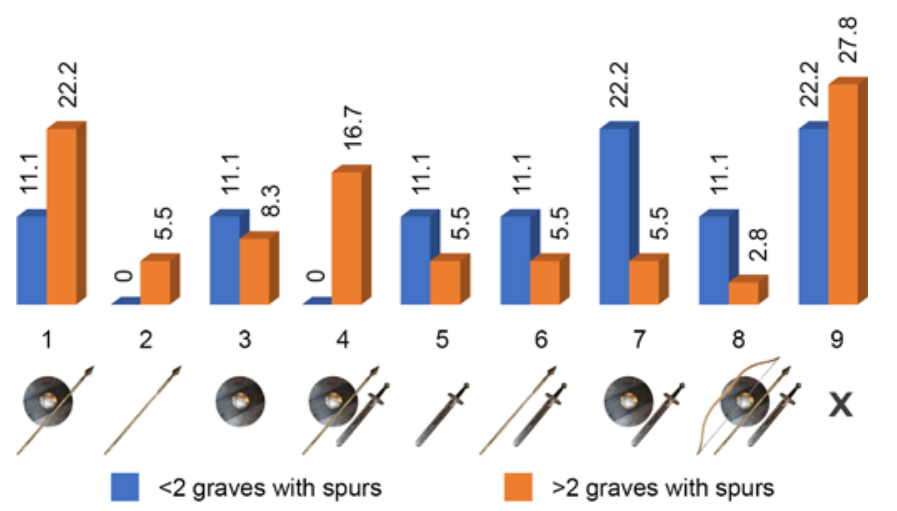

Graph 8a. Weapon sets accompanying the spurs in the cemeteries with single graves of horse riders and cemeteries with multiple graves from B1.

Graf 8a. Zbraně s ostruhami na pohřebištích s jednotlivými hroby bojovníků na koních a na pohřebištích s několika hroby ze stupně B1.

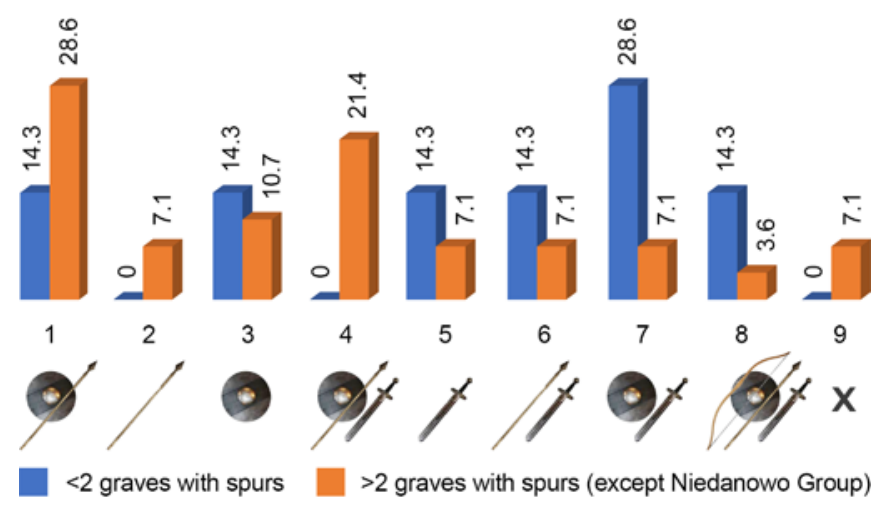

Graph $\mathbf{8 b}$. Weapon sets accompanying the spurs in the cemeteries with single graves of horse riders and cemeteries with multiple graves from B1 (except Niedanowo Group).

Graf 8b. Zbraně s ostruhami na pohřebištích s jednotlivými hroby bojovníků na koních a na pohřebištích s několika hroby ze stupně B1 (kromě skupiny Niedanowo).

These burials were dominated by three types of weapon sets: 1. Pole weapon + shield, 4 . Sword + pole weapon + shield and 9. No weapon (see Graph 8a, 8b). A large percentage of graves not equipped with weapons was caused by the significant portion of a group of burials from the north-eastern area of the Przeworsk culture, where the custom of placing weapons in the grave was uncommon, as the author mentioned earlier. To overcome the distortion resulting from the cultural distinctness of these cemeteries, analyses were also carried out with their omission, which are presented in separate graphs (Graph 8b, 9b, 10b) generated for phases B1-B2/C1. After this correction, it is possible to point to a stronger differentiation of weapons discovered in graves with spurs from cemeteries in their greater numbers, indicating the dominance of sets 1 (28.6\%) and 4 (21.4\%).

In burials with spurs, which are classified as single finds at the cemetery $(<2)$, the deceased were equipped with swords much more often $(71.5 \%$ for $<2,46.3 \%$ for $>2)$, but there were no burials containing full sets of weapons consisting of a sword, a pole weapon and a shield. A large percentage of swords in individual graves with spurs may indicate that among the smaller communities, the deceased equipped with spurs and a sword had a definite high social or military standing. Taking into account the insignificant percentage of graves equipped with sets that do

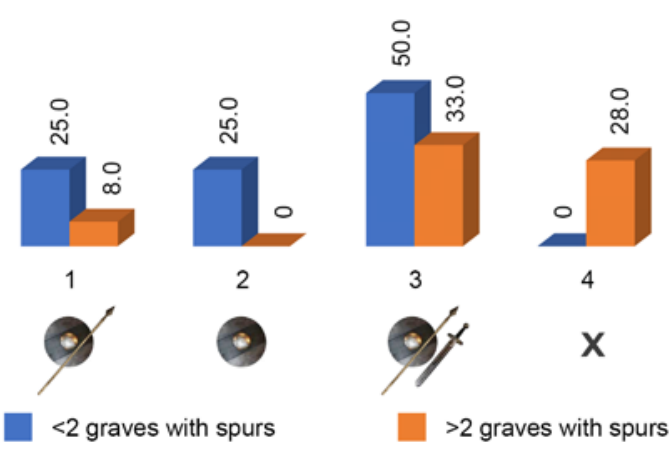

Graph 9a. Weapon sets accompanying the spurs in the cemeteries with single graves of horse riders and cemeteries with multiple graves from B2a.

Graf 9a. Zbraně s ostruhami na pohřebištích s jednotlivými hroby bojovníků na koních a na pohřebištích s několika hroby z fáze B2a.

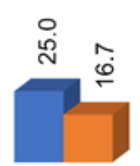

1

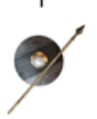

$<2$ graves with spurs

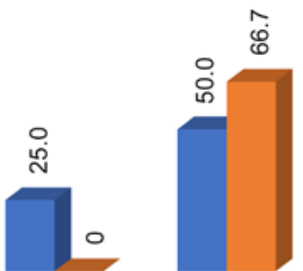

2

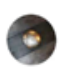

3

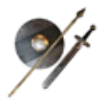

$>2$ graves with spurs (except Niedanowo Group)
Graph $\mathbf{9 b}$. Weapon sets accompanying the spurs in the cemeteries with single graves of horse riders and cemeteries with multiple graves from B2a (except Niedanowo Group).

Graf $\mathbf{9 b}$. Zbraně s ostruhami na pohřebištích s jednotlivými hroby bojovníků na koních a na pohřebištích s několika hroby z fáze B2a (kromě skupiny Niedanowo).

not contain swords, one can claim that there was an extensive military structure. The situation is different for cemeteries with more spurs, where among the burials of riders one can observe a fairly significant diversity of sets of weapons, which could suggest the existence of a form of military hierarchy among the horse warrior class.

\subsubsection{B2a}

The results of the analysis conducted for groups from phase B2a (Graph 9a, 9b) can be debatable due to their small database, which only includes 12 burials from cemeteries with multiple spurs and only 4 graves from the necropolis where they occurred individually. Nevertheless, one can observe the dominance of a rich set of weapons (set 4 . Sword + pole weapon + shield) in contrast to burials from cemeteries with single spur finds $(<2)$. It appears that the model of equipping the deceased riders with a full set of weapons replaced all other combinations containing swords that were completely missing in the current phase. Graves equipped with set No. 1 (Pole weapon + shield) set No. 3 (shield) remain on the same level.

Weaponry of horse warriors from those burial grounds, where at least a few of them were buried $(>2)$, still mostly consists of the rich full set (No. 4 - a sword, a pole weapon and 
a shield). The sole exception is represented by grave No. 60 found in Kamieńczyk, equipped with set No. 1 (Pole weapon + shield) and grave No. 30 from Opoka - not equipped with a weapon (Szarek-Waszkowska 1971; Kokowski 1991). It should be noted that there are as many as five graves without any weapons from Niedanów, for which the analysis results have been corrected.

\subsubsection{B2b phase}

In the $\mathrm{B} 2 \mathrm{~b}$ phase, one can observe an increase in the number of graves with spurs. The total number is 52 , of which 14 of which are single finds in cemeteries and 38 burials come from cemeteries with multiple spurs.

Sets of weapons discovered in burials from cemeteries where spur finds are considered individual $(<2)$ are subject to significant transformations (Graph 10a, 10b). Noticeably, there is a decrease in graves equipped with swords (from $71.5 \%$ in phase B1, $75 \%$ in phase B2a to $35.6 \%$ currently), while a number of burials were equipped with the following set: 1 . Pole weapon + shield (35.7\%), 2. Pole weapon (14.3\%) and 3. Shield (14.3\%), i.e. sets corresponding to the so-called lower rank warriors.

The weaponry of riders buried in a large cemetery, where more spurs were found (>2), such as Chorula (Szydłowski 1964), Kamieńczyk (Dąbrowska 1997), Młodzikowo, Oblin or Opoka,

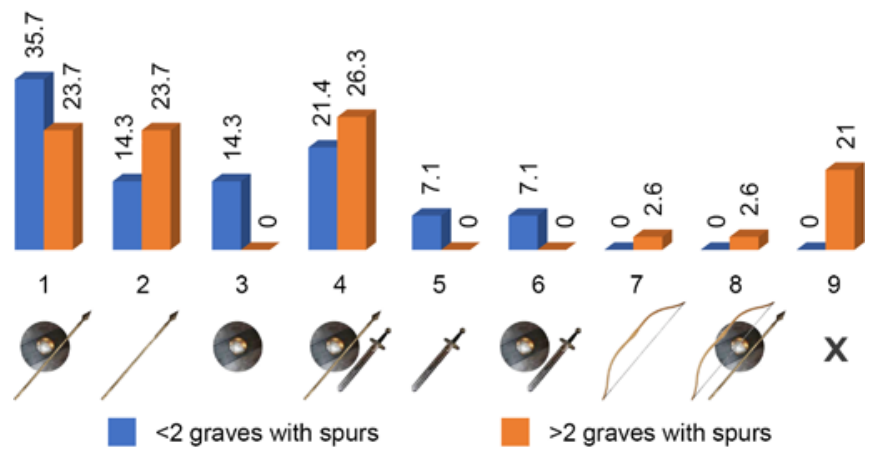

Graph 10a. Weapon sets accompanying the spurs in the cemeteries with single graves of horse riders and cemeteries with multiple graves from B2b (except Niedanowo Group).

Graf 10a. Zbraně s ostruhami na pohřebištích s jednotlivými hroby bojovníků na koních a na pohřebištích s několika hroby z fáze B2b.
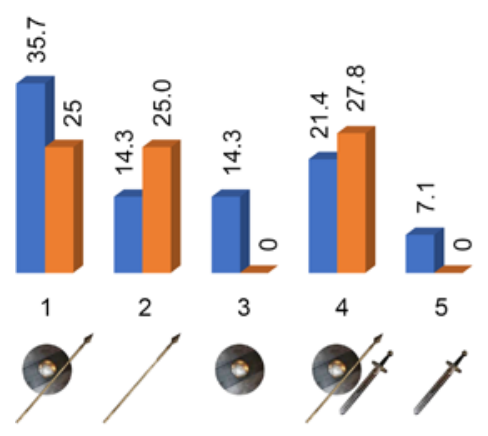

$<2$ graves with spurs

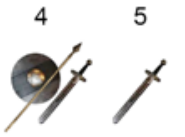

$>2$ graves with spurs (except Niedanowo Group)
Graph 10b. Weapon sets accompanying the spurs in the cemeteries with single graves of horse riders and cemeteries with multiple graves from B2b (except Niedanowo Group).

Graf 10b. Zbraně s ostruhami na pohřebištích s jednotlivými hroby bojovníků na koních a na pohřebištích s několika hroby z fáze B2b (kromě skupiny Niedanowo). indicate a specific standardisation, as three sets of weaponry prevail: 1 . Pole weapon + shield $(25 \%), 2$. Pole weapon $(25 \%)$ and 4. Sword + pole weapon + shield (27.8\%). At the same time, one can conclude there was a certain hierarchy in the ranks, where set No. 4 corresponds to the horse warrior of the highest rank, perhaps the commander, while the next two sets, No. 1 and 2, could be considered the attributes of warriors of a lower military rank.

One cannot ignore the presence of graves with spurs not equipped with any weapons, which this time cannot be explained by the specificity of the funeral rite concerning the cemeteries from the north-eastern area of Przeworsk culture. It appears that from that period, one can conclude the emergence of a symbolic custom of putting spurs into the graves of the Przeworsk culture.

\subsubsection{B2/C1}

The largest number of graves with spurs comes from the B2/C1 phase, which also includes the initial stage of the Cla phase (Graph 11). Their smaller constituent is the single finds, 19 finds of this type in the cemeteries while the larger one is the multiple finds 54 graves with spurs discovered in cemeteries of this category.

The weaponry of the buried riders from cemeteries, from which single finds of spurs originate $(<2)$ again largely fit the set containing swords (52.6\%). Considering the relatively large statistical sample, the predominance of graves equipped with a full set of weapons (as many as $36.8 \%$ of graves are equipped with a set of 4 . Sword + pole weapon + shield) appears to be deliberate. On this basis, one can conclude the stabilisation of the high position of horse warriors within the ranks of the military in smaller communities. The deceased buried with spurs with full weaponry could be considered as commanders of a local group of warriors, which included infantry.

The increase of graves equipped with swords occurred at the expense of a decrease in the share of other sets of weaponry, attributes of lower rank warriors, i.e. sets No. 1. Pole weapon + shield (21\%), 2. Pole weapon (5.3\%) and 3. Shield (5.3\%), which may additionally confirm the above assumptions regarding the increase in the importance of horse riders in smaller communities.

At the turn of the Early and Late Roman Period, there were also changes in the grave equipment of the deceased with spurs from the cemeteries that featured increased numbers $(>2)$. The number of graves not equipped with any weaponry increased more than twice (from $16.7 \%$ to $38.9 \%$ ). Most came from cemeteries in Opatów (10 graves), Wymysłowo (3), Młodzikowo (2) and Chorula (2), i.e. a large necropolis where a relatively high

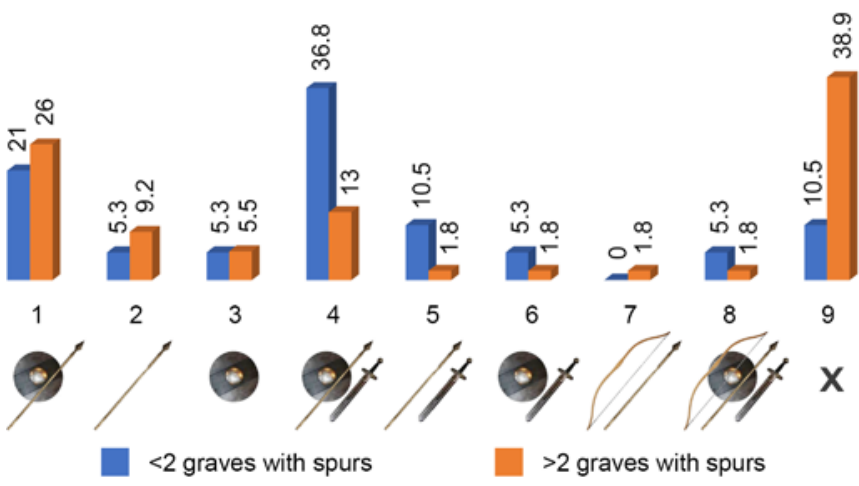

Graph 11. Weapon sets accompanying the spurs in the cemeteries with single graves of horse riders and cemeteries with multiple graves from B2/C1.

Graf 11. Zbraně s ostruhami na pohřebištích s jednotlivými hroby bojovníků na koních a na pohřebištích s několika hroby z fáze B2/C1. 


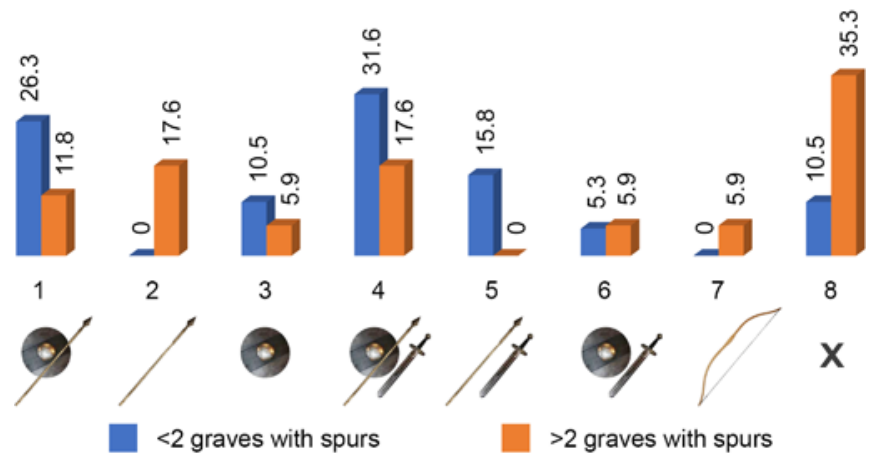

Graph 12. Weapon sets accompanying the spurs in the cemeteries with single graves of horse riders and cemeteries with multiple graves from C1a-C1b. Graf 12. Zbraně s ostruhami na pohřebištích s jednotlivými hroby bojovníků na koních a na pohřebištích s několika hroby z fázíc1a-C1b.

percentage of graves equipped with weapons were registered. Therefore, in these cases, it is impossible to explain the absence of weapons together with spurs as a generally prevailing custom of avoiding placing weapons in graves, but rather by the symbolic meaning of spurs. As previously mentioned, the problem of the symbolic meaning of spurs will not be discussed in detail. However, the author would like to refer to the progressive custom of symbolically equipping the deceased with spurs, which started in phase B1b, intensified in the B2/C1 period and at the beginning of the Late Roman Period appeared to be quite deeply rooted in the Przeworsk community culture.

The persistent diversification of weapon sets among the rest of the graves equipped with weapons may indicate a continuous hierarchy in the ranks of horsemen in a given community. However, the ratio of individual sets of weaponry appears to be much more reflective of reality. It is no longer the case that a grave equipped with the richest set of weapons was the most prevalent one (No. 4. Sword + pole weapon + shield), as its share dropped to $16.5 \%$. Graves equipped with a set with attributes of a lower rank warrior dominate: 1 . Pole weapon + shield (26\%), while much less frequent are the sets consisting of single weapon elements: 2. Pole weapon (9.2\%) and 3. Shield (5.5\%).

\subsubsection{C1a-C1b}

Among the groups of graves with spurs dated to the end of the $\mathrm{Cla}$ phase and the beginning of the $\mathrm{Clb}$ phase, it can be noted for the first time that a similar number of finds are considered as single finds (17 graves) compared to those from cemeteries with multiple finds (19 graves). However, the range and proportions of weapon sets in both analysed groups of graves with spurs do not change (cf. Graph 12). Possible changes manifest themselves in only a $+/-5 \%$ share of the sets of individual weapons. This indicates that the position of a horse warrior in the military structures defined in the previous chronological section has been firmly established.

\subsubsection{Conclusion}

The analysis of the weapons accompanying spurs in burials from cemeteries with individual finds, contrasted with those with a larger number, showed significant differences that may indicate a different significance and the role of the rider depending on the size of the social group in which they lived and were buried. In general, the vast majority of the equipment of graves that contain individual finds indicate high prestige and a high military position of the deceased. Almost throughout the entirety of the
Roman Period, these graves were equipped with swords, the percentage of which in $\mathrm{B} 1$ was $71.5 \%$ with $52.6 \%$ in the $\mathrm{B} 2 / \mathrm{C} 1$ phase and similarly $52.7 \%$ in the $\mathrm{Cla}-\mathrm{Clb}$ phase. A lower, but still high, number of graves with swords was recorded in the B2b phase. At that time, they constituted $35.6 \%$ of graves equipped with spurs. During this period, the armaments of riders, as well as foot soldiers, underwent standardisation and consisted mostly of a set of a pole weapon + shield or only a pole weapon.

The military character of the spurs in the discussed burials (from the cemeteries where $<2$ graves with spurs were discovered) is also worth emphasising. In the Early Roman Period they were almost exclusively (discounting the area of the Nidzica group) found in warrior burials. It was only at the turn of the Early and Late Roman Period that spurs began to appear in isolated burials without weapons. According to the author, this was the point when the spurs clearly took on a symbolic meaning (e.g. Fig. 6, Opatów grave 1229). Among smaller communities, this is noticeable in the form of the appearance of burials of non-warriors with spurs (in the $\mathrm{B} 2 / \mathrm{C} 1$ and the $\mathrm{Cla}-\mathrm{C} 1 \mathrm{~b}$ phases at around $10 \%$ of burials with spurs), whereas in larger cemeteries where this phenomenon was recorded from the beginning of the Common Era, there is a noticeable increase in the frequency of graves with spurs but without any weapons, which in the $\mathrm{B} 2 / \mathrm{C} 1$ phase is as high as $38.9 \%$ and slightly less at $35.3 \%$ in the $\mathrm{Cla}-\mathrm{Clb}$ phase.

A large percentage of graves with spurs but no weapons may indicate a much more complex meaning of spurs among larger communities. Additionally, one can observe a noticeable group of graves equipped with swords and burials containing sets consisting of a combination of a pole, a weapon and a shield in large cemeteries, where more spurs were discovered. On the one hand, a spur is an attribute of a rider where one can see the division into the higher and lower rank. On the other hand, spurs have a distinct symbolic overtone, which manifests itself by their presence in the graves of non-warriors. This diversity can be conditioned by a complex social structure, an extensive spectrum of beliefs and traditions, but also by the degree of wealth of the society. It can be assumed that in a rich society, spurs could be afforded not only by the commanders who were the richest and the highest on the social ladder. The second aspect is that putting spurs into a grave was associated with their exclusion from use, a sacrifice for the burial gift, which the mourners could afford.

\subsection{Sets of weapons accompanying spurs in individual cemeteries}

The context of the occurrence of spurs varies between small and large cemeteries, which does not mean that within these two groups it remains unchanged. The results of the analysis presented below indicate the nature of the occurrence of these elements of equestrian gear among particular communities, which are testified by the cemeteries studied. This analysis includes cemeteries where at least three or more spur burials were discovered. The analysis was carried out separately for a group of graves dated to the beginning of the Common Era (B1-B2a phase) and burials from the developed section of the Roman Period, i.e. $\mathrm{B} 2 \mathrm{~b}-\mathrm{B} 2 / \mathrm{C} 1$ - and the beginning of $\mathrm{Cla}$ phases. The first of these included cemeteries in Domaradzice (5 graves), Ciecierzyn (4 graves), Kamieńczyk (6 graves), Karczyn-Witowy (4 graves) and Młodzikowo (2 graves). Later periods included graves found in Ciebłowice Duże (6 graves; Dzięgielewska, Kulczyńska 2008), Chorula (14 graves), Kamieńczyk (3 graves), Krupice (5 graves; Jaskanis 2005), Lachmirowice (9 graves), Młodzikowo (8 graves), Oblin (9 graves), Opatów (8 graves), Opoka (6 graves) and Wymysłowo (4 graves). 

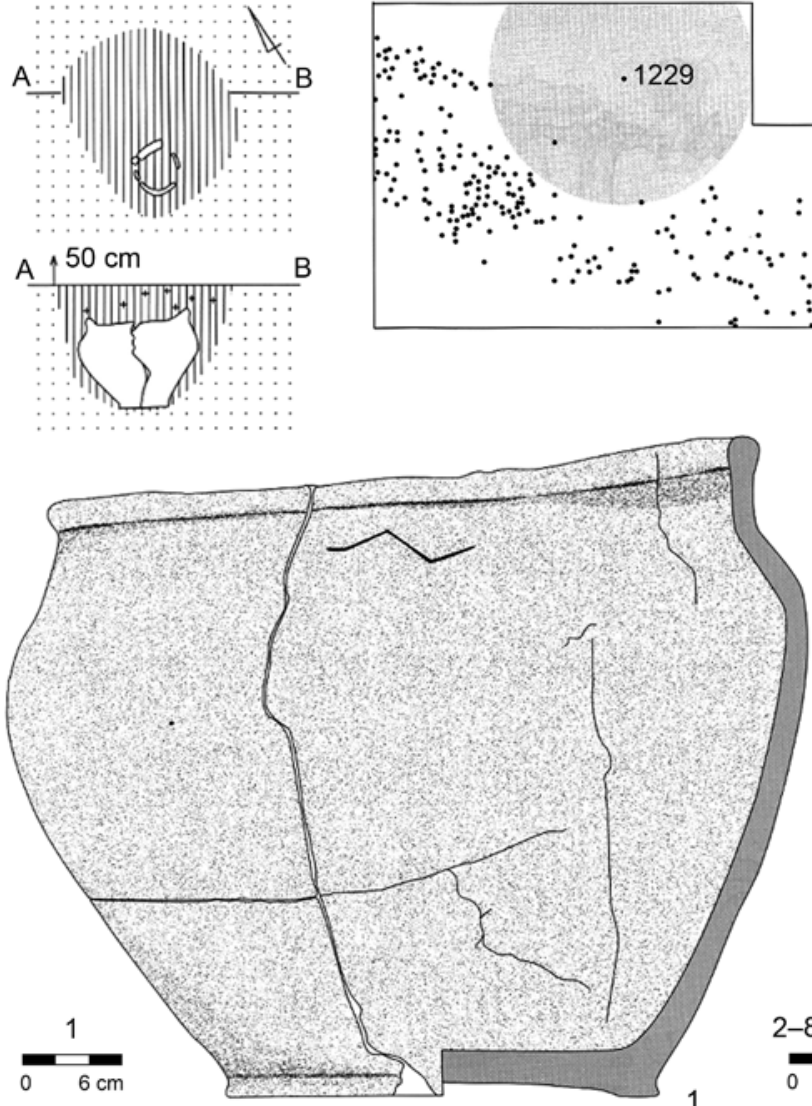

$\frac{2-8,10-16}{0,3 \mathrm{~cm}}$
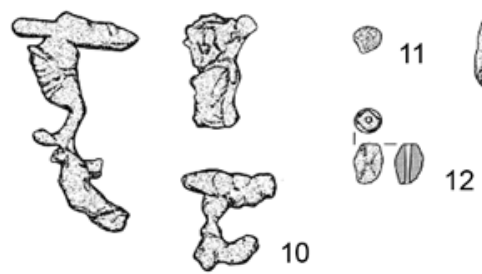

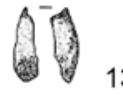
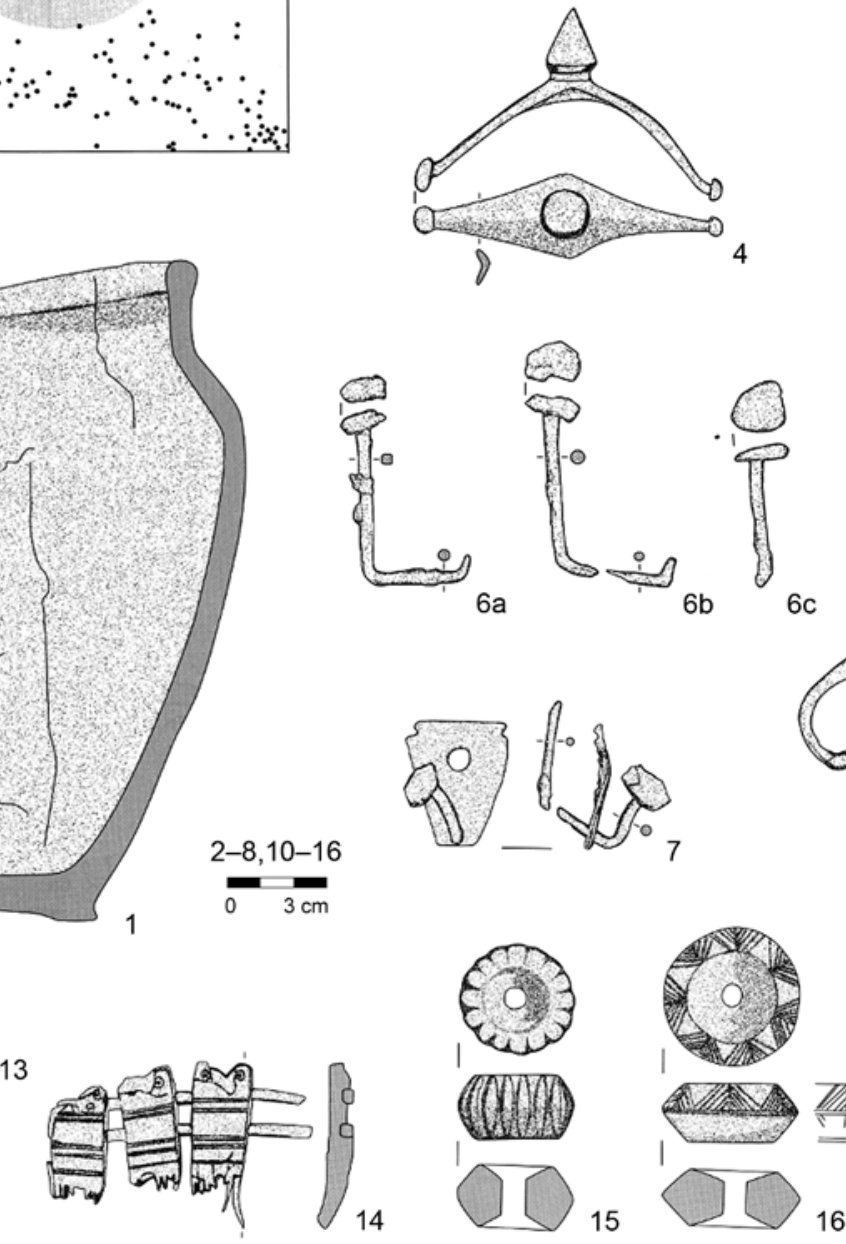
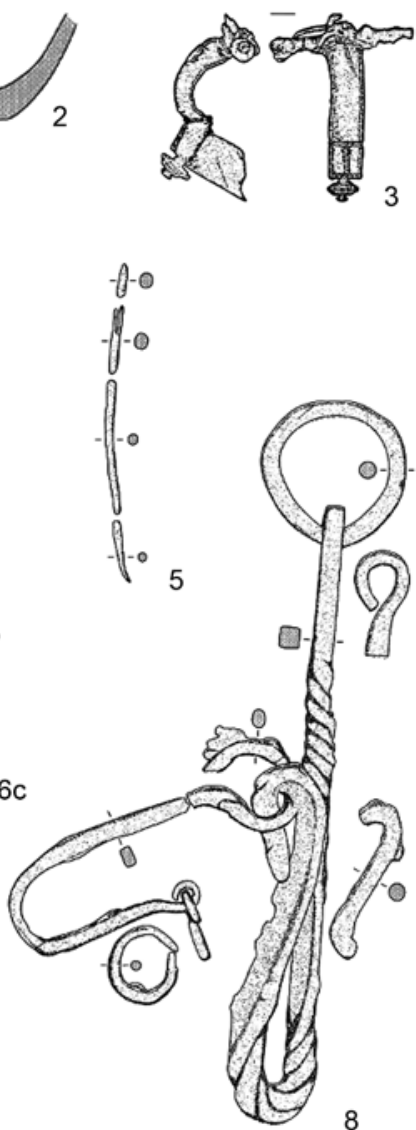

8
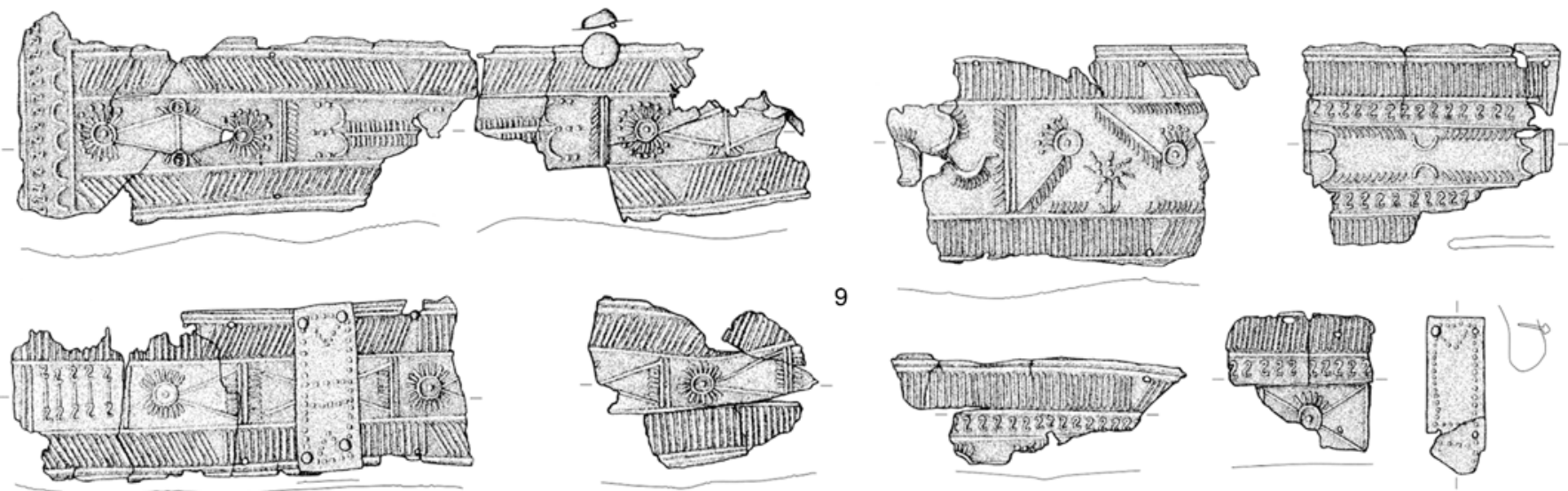

9
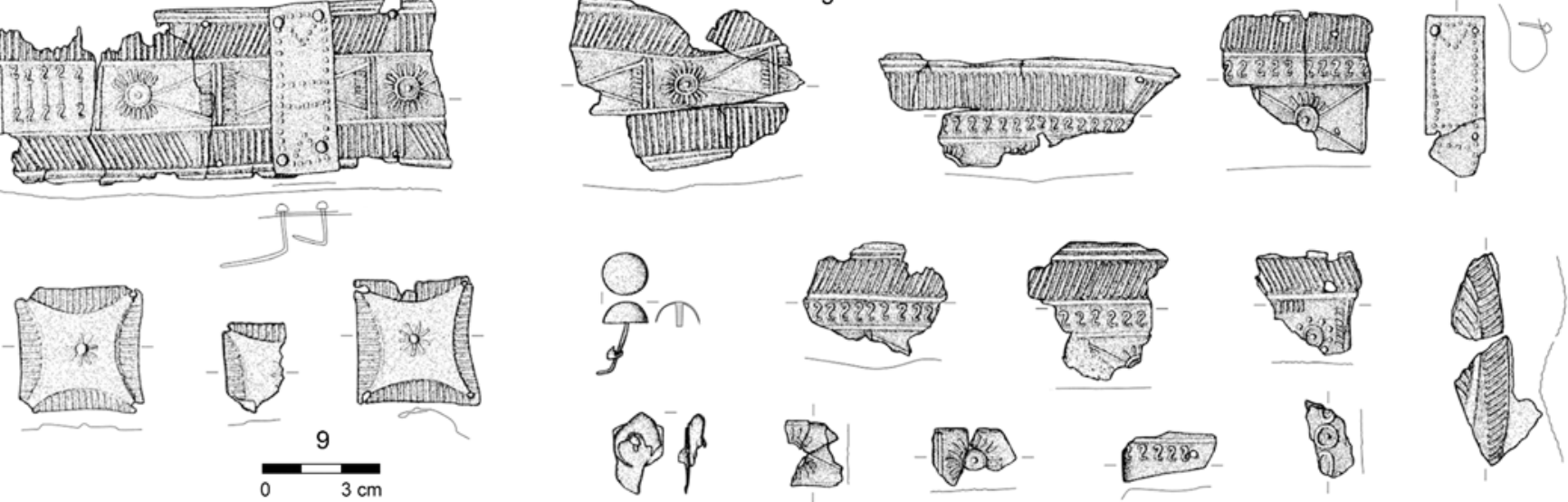

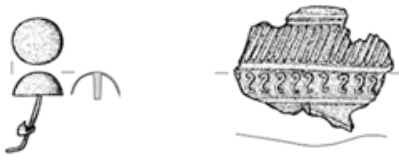

ois

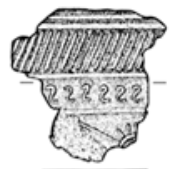

2328

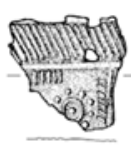

(a)

(3) 


\subsubsection{B1-B2a phase}

Data presented in the Graph 13 indicates that in cemeteries such as Domaradzice, Oblin, Kamieńczyk and Ciecierzyn with spurs from burials dated to the beginning of the Roman Period have a functional and definite military significance, as shown by the accompanying sets of weapons. In Domaradzice, three of the five burials with spurs were equipped with the set of a lower rank warrior: a pole weapon and a shield. Two other graves contained swords. The deceased buried in the first grave was armed with a sword, a pole weapon and a shield while grave No. 71 contained a single spur and a sword. In the case of this second burial, it can be assumed that the principle pars pro toto ${ }^{9}$ was applied, where a spur and a sword could symbolise the entirety of the equipment of a deceased warrior.

It appears that the deceased riders buried in the cemeteries in Kamieńczyk and Ciecierzynie were of a high military rank. In Kamieńczyk, four of the six graves with spurs contained swords and the other two were equipped with a set of a pole weapon and a shield. In Ciecierzyna, in turn, the inventory of two of the four burials consisted of swords; the other two were more modestly equipped with weapons (grave No. 141 - a pole weapon and a shield, grave No. 194 - a pole weapon). All the burials with spurs discussed above can be regarded as burials of warriors holding different positions in the military hierarchy. Thus, one can observe a strong military connotation of spurs among the communities that built these necropolises.

In the case of cemeteries in Młodzikowo and Karczyn-Witowy, dig site No. $21 / 22$, the symbolic meaning of the spurs is clearly noticeable. In Młodzikowo, one of the two burials with spurs, grave No. 188, was equipped with a set consisting of a shield and a pole weapon, which enables to classify the deceased as a warrior. Meanwhile, at the second site, grave No. 73, did not contain any weapons. An even more complex situation can be observed at the cemetery in Karczyn-Witowy, where three of the four burials with spurs were equipped with only individual weapon elements, while one does not contain any weapons at all. However, the results of the anthropological analysis are particularly intriguing. They indicate that grave No. 13 was that of a child - buried in the age of infans II - and contained, among other finds, spurs and two spears. An adult woman (20+ years old) was placed in grave No. 629, equipped with spurs and the only sword scabbard in the cemetery. In grave No. 130, which contained spurs but was devoid of weapon elements, a child was buried (age infans I/II). The grave also contained fittings of a drinking horn, rarely found in the area of Barbaricum, as well as dice and a toy stone.

\subsubsection{B2b-B2/C1}

The $\mathrm{B} 2 \mathrm{~b}$ and $\mathrm{B} 2 / \mathrm{C} 1$ phases feature the widest group of $\mathrm{fu}^{-}$ nerals with spurs from large cemeteries. Graph 14 presents the diversity of the characteristics of the presence of spurs in ten Przeworsk culture cemeteries. It was designed in a way that makes it easier to compare results. Reading the graph from left to right, one can notice that the military value of the weapon sets gradually decreases in favour of the symbolic value.

In Kamieńczyk, all graves with spurs were equipped with a weapon + shield set, the most common weapon sets in the Roman Period. Thus, it can be concluded that the spurs were definitely of a practical and military character. Similarly, in the

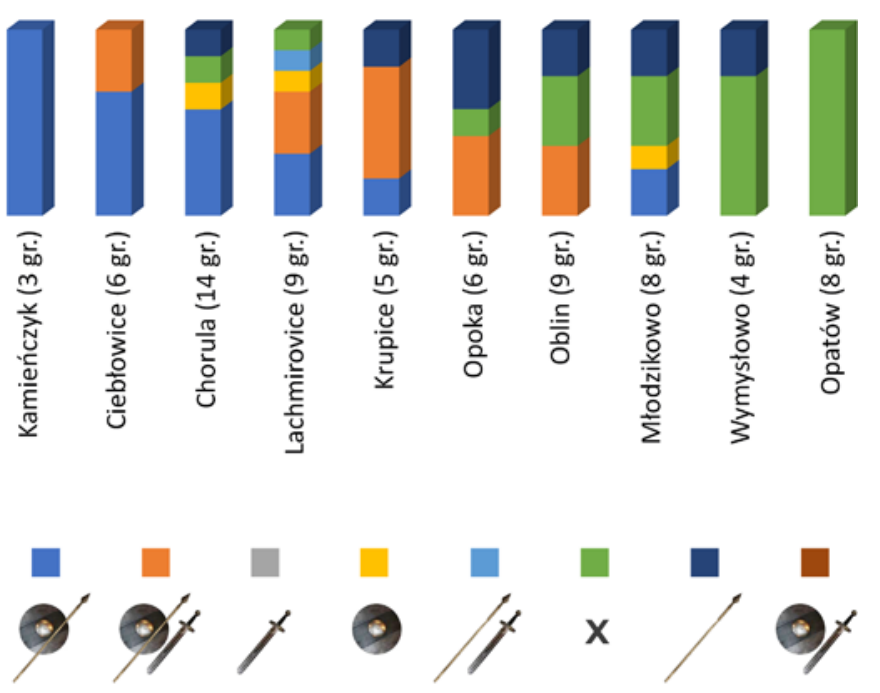

Graph 14. Weapon sets accompanying spurs in individual cemeteries in the $\mathrm{B} 2 \mathrm{~b}-\mathrm{B} 2 / \mathrm{C} 1$ phase.

Graf 14. Zbraně s ostruhami na jednotlivých pohřebištích ve fázích B2b-B2/C1.
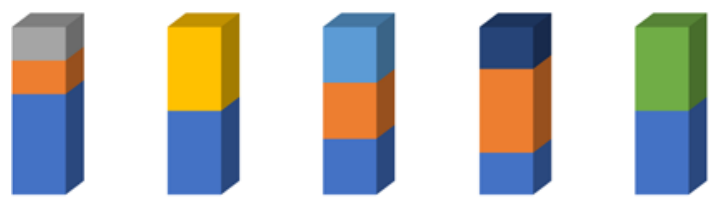

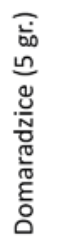

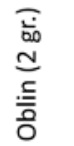

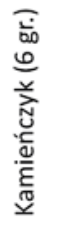

这

范

产

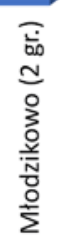
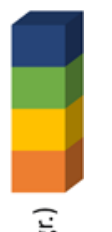

ธิँ 竡

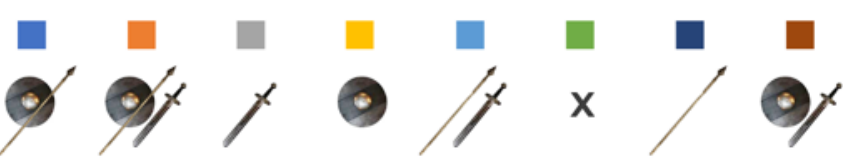

Graph 13. Weapon sets accompanying spurs in individual cemeteries in the B1-B2a phase.

Graf 13. Zbraně s ostruhami na jednotlivých pohřebištích v B1-B2a. case of the deceased in the cemeteries in Cieblowice Duże and Chorula, based on clearly militarised burial equipment, it can be presumed that they were part of the warrior caste. In the case of these two communities, it is also worth noting that there was a noticeable standardisation and unification of the horse riders' armaments. In subsequent cemeteries, weapon sets began to differentiate further and gradually the basic weapon set consisting of a pole weapon and a spear began to replace other combinations, including large rich sets containing swords. Therefore, it can be assumed that at successive cemeteries the utilitarian value of spurs decreased while the symbolic value increased. Thus, the prestige and wealth of the people buried in the company of spurs grew.

The largest number of graves with spurs containing swords were discovered in the cemeteries in Lachmirowice, Krupice and Opoka. In Lachmirowice, three burials (graves No. 17, 24 and 30) contained a full set of weapons, which consisted of a sword, a pole weapon and a shield. Grave No. 1 was equipped with a sword and a pole weapon. The sets of weapons discovered in subsequent burials with spurs were slightly more modest, 

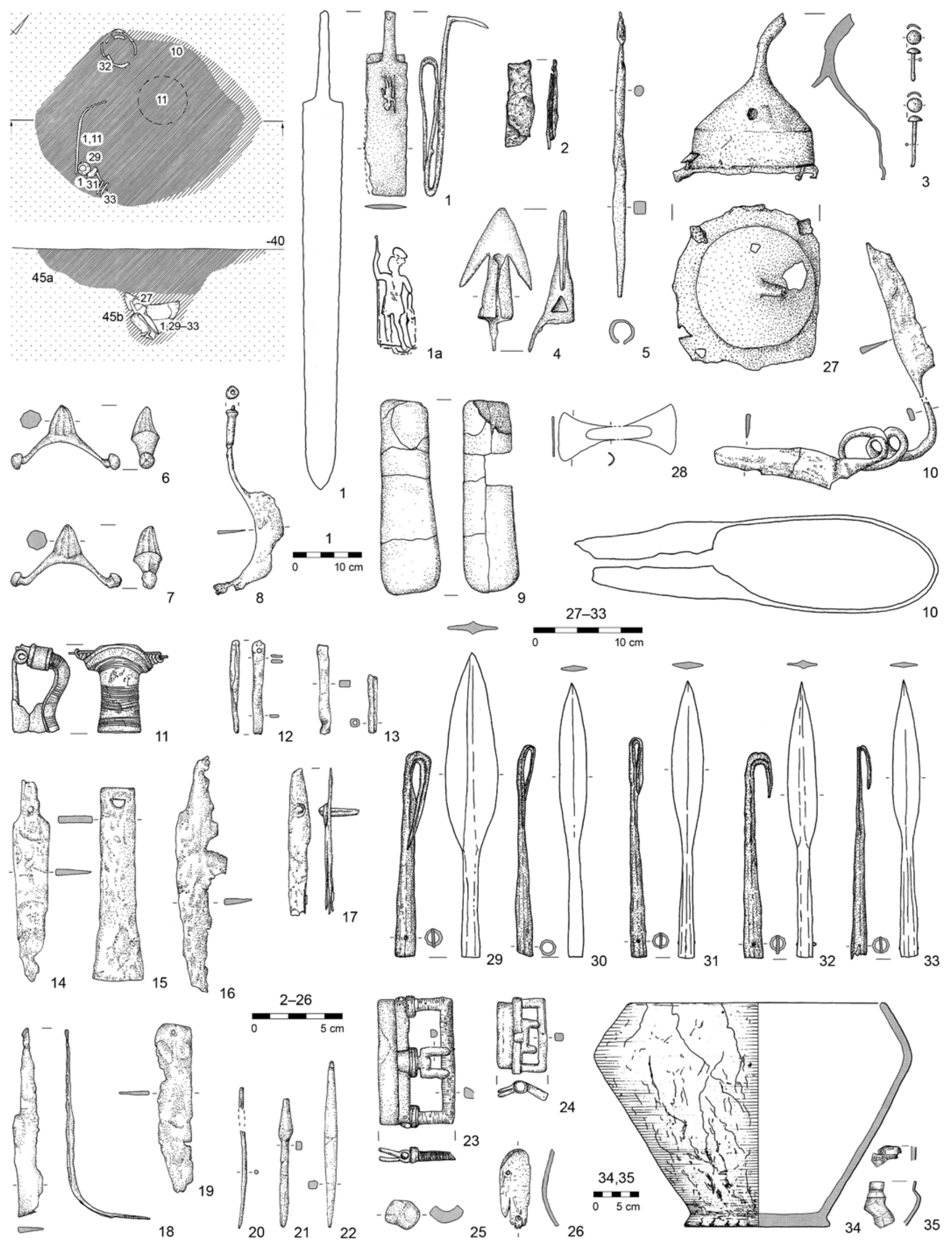

Fig. 7. Oblin, grave 45b. Pottery, silver (25, 26), stone (9) and iron items from the grave (after Czarnecka 1999, 211-215, Tabl. XLVII-L).

Obr. 7. Oblin, hrob 45b. Keramika, stříbrné (25, 26), kamenné (9) a železné předměty z hrobu (podle Czarnecka 1999, 211-215, Tabl. XLVII-L). 
including one of the graves not equipped with weapons at all. It is worth mentioning that grave No. 13 is referred to and considered by the literature as a "feminine" burial because its contents feature, apart from a single spur, a key, a casket and a clasp (Jasnosz 1952; Zielonka 1953b, 367-368). At the necropolis in Krupice, all the five horsemen were equipped with sets of weaponry; three of them, the richest, contained a sword, a pole weapon and a shield (graves No. 106, 134 and 332/1). Burials of three deceased with weapons also come from the cemetery in Opoka (graves No. 18, 75 and 95). However, the wealth of these finds contrasts with the inventory of the remaining analysed graves from this site because three of them contained only elements of pole weapons (graves No. 11, 24 and 98) while the fourth, grave No. 88 , did not contain any weapons.

The results presented here clearly indicate an increase in the symbolic value of the spurs in the community that was responsible for the cemeteries in Oblin, Młodzikowo, Wymysłowo and Opatów. At the necropolis in Oblin, the prestige of the deceased equipped with spurs is clearly visible in the equipping of as many as one-third of them (graves No. 45b, 52 and 62) with a full set of weapons (a sword, a pole weapon and a shield). Grave No. 45b is particularly noteworthy - not only because of the extraordinarily rich equipment present, including weapons, tools and elements of the outfit but also because of the interesting non-standard spatial layout, described by Katarzyna Czarnecka (Fig. 7, Oblin grave $45 \mathrm{~b}$ ). According to the interpretation of the cited researcher, the richly equipped grave No. $45 \mathrm{~b}$ was placed under the foot of an older one (from the A3 phase of the Late Pre-Roman Period) - also a well-equipped grave with the designation of 45a (Czarnecka 1999, 165-168). It should be added that abundant equipment was not, it appears, the only way to emphasise the importance of these graves and the people buried in them. These burials were located inside a fairly regular circle created by clearly less intensively equipped graves (Smólka-Antkowiak, Ciesielski 2019). Given the above, it can be presumed that the deceased belonged to the social elite, potentially the military elite. Three more burials from Oblin, indicating the symbolic role of the spurs, are graves numbered 33, 51 and 72 and not equipped with any weapons. The first grave contained the body of a child in the age of infans I/II, buried with two spurs, rarely found in the area of the Przeworsk culture, but more often within the domain of the Wielbark culture. In addition to the spurs, the grave also included an imported glass vessel (Czarnecka 2007). The remaining burials with spears from Oblina were equipped with individual weapon elements.

A large percentage of graves with spurs not equipped with weapons were also recorded at the Młodzikowo Cemetery. These are graves numbered 15, 106 and 169. Grave No. 15 is of particular interest as together with several others it formed a grouping of urnfield graves, clearly spatially distinctive and equipped differently in the context of the cemetery in Młodzikowo (Smółka-Antkowiak, Ciesielski 2019). In Wymyslowo, as many as three of the four graves with spurs dated to this period were devoid of any weapons. The uniqueness of the deceased buried in these graves is highlighted by the set of gifts placed in the grave. Grave No. 176, features a bronze spur, bronze vessel fragments and a terra sigillata (Jasnosz 1952). Grave No. 177, like the above-mentioned grave No. 13 of Lachmirowice, contained the remains equipped with a typically "feminine" set, which consisted of chest-lock fittings and a needle, and among others, a fragment of a bronze vessel (Jasnosz 1952). In addition, it should be emphasised that the spur discovered in this grave, like the specimen from grave No. 176, was made of bronze.
The unusually symbolic character of the spurs is visible in the example of a large necropolis in Opatów where none of the eight graves dated to the extended section of the Roman Period (B2/C2-Cla) contained weapons and their equipment can be described as modest. The one exception is grave No. 1229, which contained the body of a mature woman. The grave is equipped with a single spur, probably two bronze and one silver clasp, a unique, richly decorated bronze casket, a needle, a comb, two spindles and glass, presumably from a molten vessel. It is also worth noting that this burial was most probably a burial mound because it was located at a considerable distance, about $15 \mathrm{~m}$, from other objects dated to the earlier stage of the Late Roman Period and formed a compact cluster in this part of the cemetery (Zagórska-Telega 2000, 314). The sex of the deceased, although not typical for burials with spurs, in the case of the necropolis of Opatów is not surprising because most of these types of graves dating back to the beginning of the late Roman Period contained the remains of women and children in the age of infans I (Madyda-Legutko et al. 2011).

\section{Conclusion}

To conclude, spurs found in graves in the context of the area of the Przeworsk culture appear to have many meanings. The current level of research excludes the possibility of the unequivocal determination of graves with spurs as only the graves of men or warriors. Nevertheless, a large share of burials containing military items indicates that it is possible to interpret the majority of graves containing this category of equestrian gear as those of warriors. This analysis showed significant differences, particularly regarding the wealth of the weapon sets of horse warriors in relation to foot soldiers, thus confirming the thesis about the high wealth and social status of the dead buried with spurs. Deceased riders also occupied a high position in the military structure and it can be assumed that the military commanders came from the ranks of horse warriors. This is indicated by the analysis of the armaments of the individual riders buried among smaller communities, which showed that they were most often equipped with the richest sets of weapons including swords. Among the riders buried in larger groups in the cemetery, one can still find wealthy sets, but this time more diversified. This may suggest a division between a commander and the lower-ranking warriors in the cavalry.

The analysis carried out also shows that the changes the occurred in the equestrian warrior's gear were somewhat independent of changes in the weaponry sets of the foot soldiers. The "enrichment" of weapon sets following the wars on the Roman limes was mainly related to horse riders.

The existing differences in the degree of the militarisation of burials with spurs were conditioned by time and space. Spurs are mainly a utilitarian object - an attribute of a warrior at the beginning of the Common Era - that over time acquired a symbolic meaning, which is manifested by their presence in burials not equipped with any weapons and often belonging to women and children. It should be emphasised that the share of graves equipped and not equipped with weapons is different for individual communities. The last analysis showed that a spur was only of military significance for some human groups while for others it was more often a gift or a symbol, with only a presumed meaning.

\section{Notes}

1 Regardless of the fact that some archaeological literature on the Przeworsk culture, including analyses, have already been published several times (Elantkowska 1961; Kaczanowski 1976; Weski 1982; Gojda 1984), it is B. Kontny's works that can be considered as the most current and, at the same time, 
the most exhaustive (Kontny 2002; 2003a; 2003b). They form a comprehensive approach to the issue of diversity of weapon sets, which comprised the equipment in graves discovered in connection with the Przeworsk culture.

2 The research conducted by the author shows that graves with spurs usually belonged to the richest burials found in the cemeteries. However, the term "rich burial" is a very relative, locally conditioned concept, contextualised by the wealth of a given community. For example, a burial equipped with spurs, arrowheads, a shield boss, a brooch and a comb could be common in one cemetery, while elsewhere it may belong to some of the richest burials. Thus, "the wealth of the grave" is not always associated with imported goods, for example, but with richer-than-average equipment of the deceased within a given cemetery.

3 However, these are such rare finds that they do not enable to recognise the bow as a category of weapon commonly used by this community. In addition, it is not certain whether the bow in general was ever regarded and considered as a military weapon in the Przeworsk culture. Rather, it indicates the possibility that the bow was used during hunting, not necessarily fighting (Kontny 2006, 72). Despite the above ambiguities, for the purposes of this analysis, the bow was identified as a separate category of weapon, which enables to verify the marginality of its possible use in arming the horse warriors of that community.

4 The chronological division adopted in the work is based on the division used by B. Kontny (2003a, 113), which, in turn, takes into account the dating of graves with weapons by K. Godlowski $(1992 ; 1994)$. The adoption of an analogous division allows for an unrestricted comparison of the results obtained to those of Kontny. In total, six chronological phases were ascribed for the Roman Period: B1 phase (between $10 \mathrm{CE}$ and 75/80 CE), B2a (between 75/80 CE and the 2nd century), B2b (around $160 \mathrm{CE}$ ), B2/C1 (up to $200 \mathrm{CE}$ ), late Cla phase and C1b phase (up to $260 \mathrm{CE}$ ), C2-D (up to the 5th century). Based on the dating classification of T. Dąbrowska (1988) and K. Godłowski (1985; 1992; 1994; cf. Kaczanowski, Kozłowski 1998, 265-278).

5 The author considers it justified to separate the category of graves with spurs without weapons as spurs can be treated as part of the weaponry. Spurs are seen as a weapon element by many researchers, including B. Kontny.

6 B. Kontny already mentioned this relationship (Kontny 2003a, 124) with no real justification for the reduction in the number of swords (and spurs) in B2a phase graves.

7 These changes concerned burial forms, i.e. the deceased were buried in shallower, trough graves or more often than before in urn-less graves. General impoverishment of the grave equipment occurred and new forms of graves appeared later, among others, cremation layered graves (Godłowski 1985, 91; Godłowski 1992, 83; Błażejewski 1998, 89-93, Kontny 2002, 110).

8 The author wishes to emphasise once again that such terms as "horse riders", "horse warriors" and others used herein refer only to some of the dead buried in graves containing spurs. Therefore, these terms are used here with the awareness of their generalisation.

9 This possibility was indicated by B. Kontny in the case of graves equipped with individual elements of armament that do not reflect the actual armament of a warrior (Kontny 2002; 2003a).

\begin{tabular}{|c|c|c|c|c|}
\hline Site & $\begin{array}{l}\text { Commune (administrative } \\
\text { district, municipality) }\end{array}$ & County & Voivodeship & References \\
\hline Adolfin & Dobre & Radziejów & Kujawsko-pomorskie & Zielonka 1953a, 1961a \\
\hline Biała, site 1 & Zgierz & Zgierz & Łódzkie & Makiewicz 1970 \\
\hline Bodzanowo & Zakrzewo & Aleksandrów & Kujawsko-pomorskie & Zielonka 1958, 1961b \\
\hline Bogomice & Kotla & Głogów & Dolnośląskie & Petersen 1934 \\
\hline Bolesław & Bolesław & Dąbrowa & Małopolskie & Jamka 1967 \\
\hline Brodno & Środa Śląska & Środa & Dolnośląskie & Anonym 1926 \\
\hline Budy Łańcuckie & Białobrzegi & Łańcut & Podkarpackie & Osiński 1923 \\
\hline Chłopice & Chłopice & Jarosław & Podkarpackie & Franz 1932 \\
\hline Chmielów Piaskowy & Bodzechów & Ostrowiec & Świętokrzyskie & Godłowski, Wichman 1998 \\
\hline Chorula & Gogolin & Krapkowice & Opolskie & Szydłowski 1964 \\
\hline Ciebłowice Duże & Tomaszów Mazowiecki & Tomaszów Mazowiecki & Łódzkie & Dzięgielewska, Kulczyńska 2008 \\
\hline Ciecierzyn & Byczyna & Kluczbork & Opolskie & Martyniak et al. 1997 \\
\hline Dębnica & Prusice & Trzebnica & Dolnośląskie & Kaletyn 1963 \\
\hline Domanowice & Trzebnica & Trzebnica & Dolnośląskie & Błażejewski 1998 \\
\hline Domaradzice & Jutrosin & Rawicz & Wielkopolskie & Kostrzewski 1954 \\
\hline Domaradzyn & Głowno & Zgierz & Łódzkie & Piętka-Dąbrowska 1960 \\
\hline Drochlin & Lelów & Częstochowa & Śląskie & Kaczanowski 1972 \\
\hline Drohiczyn & Drohiczyn & Siematyce & Podlaskie & Szmit 1921 \\
\hline Głogów & Głogów & Głogów & Dolnośląskie & Tackenberg 1925 \\
\hline Głogów-Nosocice & Głogów & Głogów & Dolnośląskie & Tackenberg 1925; Pescheck 1936 \\
\hline Gojewa Góra & Warta & Sieradz & Łódzkie & Svešnikov 1957 \\
\hline Grodzisk Mazowiecki & Grodzisk & Grodzisk & Mazowieckie & Barankiewicz 1959 \\
\hline Gródki & Płośnica & Działdowo & Warmińsko-mazurskie & Okulicz 1983 \\
\hline Grudynia Mała & Pawłowiczki & Kędzierzyn-Koźle & Opolskie & Jahn 1921 \\
\hline Inowrocław site. 55 & Inowrocław & Inowrocław & Kujawsko-pomorskie & Zielonka 1970 \\
\hline Inowrocław „na Batkówku” & Inowrocław & Inowrocław & Kujawsko-pomorskie & Bednarczyk 1994 \\
\hline Kamieńczyk & Wyszków & Wyszków & Mazowieckie & Dąbrowska 1997 \\
\hline Karczyn/Witowy & Kruszwica & Inowrocław & Kujawsko-pomorskie & Bednarczyk, Romańska 2015 \\
\hline Komorówko & Trzebnica & Trzebnica & Dolnośląskie & Pescheck 1939 \\
\hline Konin & Konin & Konin & Wielkopolskie & Kostrzewski 1947; Pieczyński 1967 \\
\hline
\end{tabular}




\begin{tabular}{|c|c|c|c|c|}
\hline Site & $\begin{array}{l}\text { Commune (administrative } \\
\text { district, municipality) }\end{array}$ & County & Voivodeship & References \\
\hline Kopki & Rudnik & Nisko & Podkarpackie & Jamka 1935 \\
\hline Korytnica & Korytnica & Jędrzejowski & Świętokrzyskie & Skurczyński 1947 \\
\hline Kotla & Kotla & Glogów & Dolnośląskie & Kaczmarek 1962 \\
\hline Krajanka & Czastary & Wieruszów & Łódzkie & Abramek, Kaszewski 1973 \\
\hline Krapkowice & Krapkowice & Krapkowice & Opolskie & Mączyńska 1971 \\
\hline Krupice & Siemiatycze & Siemiatycze & Podlaskie & Jaskanis 2005 \\
\hline Kryspinów & Liszki & Kraków & Małopolskie & $\begin{array}{l}\text { Godłowski 1972; 1976a; 1976b; } \\
\text { Godłowski, Mączyńska } 1972\end{array}$ \\
\hline Kurza, site 2 & Blizanów & Kalisz & Wielkopolskie & Olędzki, Teske 1987 \\
\hline Kutno- Józefów & Kutno & Kutno & Łódzkie & Moszczyński 1994, 1996 \\
\hline Lachmirowice & Kruszwica & Inowrocław & Kujawsko-pomorskie & Zielonka 1951, 1953b \\
\hline Lisów & Grójec & Grójec & Mazowieckie & Karpińska 1926; Kietlińska 1974 \\
\hline Eęgonice Małe & Odrzywół & Przysucha & Mazowieckie & Liana 1976; Kordowska, Kowalska 2018 \\
\hline Miksztal & Nowe Ostrowy & Kutno & Łódzkie & Lepówna 1956 \\
\hline Młodzikowo & Krzykosy & Środa Wielkopolska & Wielkopolskie & Dymaczewski 1958 \\
\hline Modła & Wiśniewo & Mlawa & Mazowieckie & Grzymkowski 1986 \\
\hline Mokra & Miedźno & Kłobuck & Śląskie & Biborski 1998 \\
\hline Nadkole & Łochów & Węgrów & Mazowieckie & Andrzejowski 1998 \\
\hline Niedanowo & Kozłowo & Nidzica & Mazowieckie & Ziemlińska-Odojowa 1999 \\
\hline Oblin & Maciejowice & Garwolin & Mazowieckie & Czarnecka 2007 \\
\hline Ochędzyn Nowy & Sokolniki & Wieruszów & Łódzkie & Ząbkiewicz-Koszańska 1973 \\
\hline Opatów, site 1 & Opatów & Kłobuck & Śląskie & Madyda-Legutko et al. 2011 \\
\hline Opoka & Końskowola & Pulawy & Lubelskie & Szarek-Waszkowska 1971; Kokowski 1991 \\
\hline Opoki & Aleksandrów Kujawski & Aleksandrów & Kujawsko-pomorskie & Bednarczyk 1994 \\
\hline Piaski & Kleszczów & Bełchatów & Łódzkie & Skowron 1997 \\
\hline Piastowo-Pajki & Krzynowłoga Mała & Przasnysz & Mazowieckie & Peiser 1916 \\
\hline Podlodów & Laszczów & Tomaszów & Lubelskie & Gruba, Ślusarski 1966 \\
\hline Rzeszów-Zalesie, site 93 & Rzeszów & Rzeszów & Podkarpackie & Czopek 1998 \\
\hline Sandomierz-Krakówka & Sandomierz & Sandomierz & Świętokrzyskie & Wilkoński 1938; Kokowski, Ścibior 1990 \\
\hline Siedlemin & Jarocin & Jarocin & Wielkopolskie & Karpińska 1926; Janiczak 1990 \\
\hline Siemianice & Łęka Opatowska & Kępno & Wielkopolskie & $\begin{array}{l}\text { Szembekówna 1902; 1905; 1909a; 1909b; } \\
\text { Kostrzewski } 1923\end{array}$ \\
\hline (Stara) Sobótka & Grabów & Łęczyca & Łódzkie & Rycel 1983 \\
\hline Spycimierz & Uniejów & Poddębice & Dolnośląskie & Kietlińska, Dąbrowska 1963 \\
\hline Stara Wieś & Węgrów & Węgrów & Mazowieckie & Radig 1942 \\
\hline Strupina & Prusice & Trzebnica & Dolnośląskie & Pfutzenreiter 1929 \\
\hline Stupsk & Stupsk & Mława & Mazowieckie & Grzymkowski 1996 \\
\hline Ścinawa & Ścinawa & Lubin & Dolnośląskie & Anonym 1934 \\
\hline Tarnów Opolski & Tarnów Opolski & Opole & Opolskie & Godłowski, Szadkowska 1972 \\
\hline Walichnowy & Sokolniki & Wieruszów & Łódzkie & Ząbkiewicz-Koszańska 1966-1967 \\
\hline Wesółki, site 5 & Blizanów & Kalisz & Wielkopolskie & Kozłowska 1972 \\
\hline Witaszewice & Góra Świętej Małgorzaty & Łęczyca & Eódzkie & Kaszewska 1973; Kaszewska et al. 1974 \\
\hline Wola Blędowa & Stryków & Zgierz & Łódzkie & Blombergowa 1972 \\
\hline Wólka Domaniowska & Przytyk & Radom & Mazowieckie & Olędzki 1994 \\
\hline $\begin{array}{l}\text { Wrocław-Pracze } \\
\text { Odrzańskie }\end{array}$ & Wrocław & Wrocław & Dolnośląskie & Pescheck 1939 \\
\hline Wrzask-Zagłoba & Stryków & Zgierz & Łódzkie & Siciński 1988 \\
\hline Wymysłowo & Krobia & Gostyń & Wielkopolskie & Jasnosz 1952 \\
\hline Zadowice, site 1 & Godziesze Wielkie & Kalisz & Wielkopolskie & $\begin{array}{l}\text { Abramowicz 1956; Abramowicz, } \\
\text { Lepówna 1957; Kaszewska } 1975\end{array}$ \\
\hline Zaspy & Warta & Sieradz & Łódzkie & Kostrzewski B. 1939 \\
\hline Żerków & Żerków & Jarocin & Wielkopolskie & Kočka 1939 \\
\hline Site & District & Region & Country & References \\
\hline Bratovo (Batyu) & Vinogradov & Zakarpattia & Ukraine & Kobal’ 1997 \\
\hline Hromówka & Chmiel'nic'kij & Chmiel'nic'kij & Ukraine & Dąbrowska, Godłowski 1970 \\
\hline Griniv & Pustomyty & Lviv & Ukraine & Kozak 1985 \\
\hline Iwane-Zolote & Zaliszczyky & Ternopilśka & Ukraine & Śmiszko 1932 \\
\hline Kamianka Velykaja & Kolomyia & Ivano-Frankivsk & Ukraine & Śmiszko 1932; Kozak 1984 \\
\hline Petryłów & Tlumach & Ivano-Frankivsk & Ukraine & Śmiszko 1932 \\
\hline Welikaja Ternewa & no data & Chmiel'nic'kij & Ukraine & Kropotkin 1977 \\
\hline
\end{tabular}

Tab. 1. List of sites comprising the material base for the analysis of graves with spurs.

Tab. 1. Seznam lokalit představující materiální základnu pro analýzu hrobů s ostruhami. 


\section{Acknowledgement}

This article was created as part of the project funded by the Polish National Science Center (NCN) UMO-2017/27/N/ HS3/00181, titled Horsemen in social structures of the Central European Barbaricum. Spatial analysis of the dispersion of spurs in cemeteries.

\section{References}

Abramek, B., Kaszewski, Z. 1973: Materiały z cmentarzyska w Krajance, pow. Wieruszów. Prace i Materiaty Muzeum Archeologicznego $i$ Etnograficznego $w$ Łodzi, Seria Archeologiczna 20, 81-110.

Abramowicz, A. 1956: Materiały z cmentarzyska w Zadowicach pow. Kalisz. Prace i Materiaty Muzeum Archeologicznego $i$ Etnograficznego $w$ Łodzi, Seria Archeologiczna 1, 61-95.

Abramowicz, A., Lepówna, B. 1957: Materiały z cmentarzyska w Zadowicach pow. Kalisz (part II). Prace $i$ Materiaty Muzeum Archeologicznego i Etnograficznego w Łodzi, Seria Archeologiczna 2, 25-51.

Andrzejowski, J. 2001: Wschodnia strefa kultury przeworskiej - próba definicji. Wiadomości Archeologiczne LIV (1995-1998), 59-87.

Andrzejowski, J. 1998: Nadkole 2. A Cemetery of the Przeworsk Culture in Eastern Poland. Monumenta archaeologica barbarica V. Kraków: Secesja.

Anonym 1926: Der vorgeschichtlichen Sammlung des Schlesischen Museums für Kunstgewerbe und Altertümer. Altschlesien 1, 263-276.

Anonym 1934: Bemerkung der Sammlung des Landesamts für vorgeschichtliche Denkmalpflege. Altschlesien 4(4), 202-209.

Barankiewicz, B. 1959: Cmentarzysko z okresu rzymskiego w Grodzisku Mazowieckim. Materiaty Starożytne V, 191-231.

Bednarczyk, J. 1994: Sépultures de la civilisation de Przeworsk en Couiavie. Inventaria Archaeologica. Pologne LXVI, Fascicule Pl 397-403. Łódź: Państwowe Wydawnictwo Naukowe.

Bednarczyk, J., Romańska, A. 2015: Karczyn/Witowy, stan. 21/22. Birytualne cmentarzysko kultury przeworskiej z Kujaw. Poznań-Inowrocław: Instytut Prahistorii UAM, Fundacja Ochrony Dziedzictwa Kulturowego Społeczeństw Kujaw „Cuiavia“.

Biborski, M. 1978: Miecze z okresu wpływów rzymskich na obszarze kultury przeworskiej. Materiaty Archeologiczne XVIII, 53-165.

Biborski, M. 1998: Badania wykopaliskowe na cmentarzysku kultury przeworskiej z okresu wpływów rzymskich w Mokrej, województwo częstochowskie. In: E. Tomczak (red.): Badania archeologiczne na Górnym Śląsku i ziemiach pogranicznych w 1995 roku. Katowice: Centrum Dziedzictwa Kulturowego Górnego Śląska, 63-75.

Blombergowa, M. 1972: Cmentarzysko z młodszego okresu rzymskiego w Woli Błędowej, pow. Brzeziny. Wiadomości Archeologiczne XXXVII(2), 170-205.

Błażejewski, A. 1998: Obrządek pogrzebowy kultury przeworskiej na Śląsku. Wrocław: Katedra Archeologii Uniwersytetu Wroclawskiego.

Czarnecka, K. 1999: O pozornej niezgodności stratygraficznej. Dwa ciekawe groby z cmentarzyska kultury przeworskiej w Oblinie, pow. garwoliński. In: J. Andrzejowski, K. Czarnecka (red.): Comhlan. Studia z archeologii okresu przedrzymskiego i rzymskiego w Europie Środkowej dedykowane Teresie Dąbrowskiej w 65. rocznicę urodzin. Warszawa: Fundacja Przyjaciół Instytutu Archeologii Uniwersytetu Warszawskiego, 165-177.

Czarnecka, K. 2007: Oblin. Ein Gräberfeld der Przeworsk-Kultur im Südmasowien. Monumenta archaeologica barbarica V. Warszawa: Państwowe Muzeum Archeologiczne, Fundacja Monumenta Archaeologica Barbarica.

Czopek, S. 1998: Kamień-brąz-żelazo. Zarys archeologii Polski potudniowo-wschodniej. Rzeszów: Wydawnictwo Muzeum Okręgowego: Rzeszowski Oddział Stowarzyszenia Naukowego Archeologów Polskich.
Dąbrowska, I., Dąbrowski, K. 1967: Cmentarzysko z okresów późnolateńskiego i wpływów rzymskich w Wesótkach, pow. Kalisz. Wrocław: Instytut Historii Kultury Materialnej Polskiej Akademii Nauk.

Dąbrowska, T. 1988: Wczesne fazy kultury przeworskiej. Chronologiazasięg - powiq̨zania. Warszawa: Państwowe Wydawnictwo Naukowe.

Dąbrowska, T. 1997: Kamieńczyk. Ein Gräberfeld der Przeworsk-Kultur in Ostmasowien. Monumenta archaeologica barbarica III. Kraków: Secesja.

Dąbrowska, T., Godłowski, K. 1970: Grób kultury przeworskiej z Hromówki na Ukrainie. Zeszyty Naukowe Uniwersytetu Jagiellońskiego. Prace archeologiczne 12, 77-102.

Dymaczewski, A. 1958: Cmentarzysko z okresu rzymskiego w Młodzikowie pow. Środa. Fontes Archaeologici Posnanienses VIII-IX (1957-1958), 179-443.

Dzięgielewska, M., Kulczyńska, M. 2008: Ciebtowice Duże. Ein Gräberfeld der Przeworsk-Kultur in südwestlichen Masowien. Monumenta archaeologica barbarica XIV. Warszawa: Fundacja Monumenta Archeologica Barbarica, Państwowe Muzeum Archeologiczne.

Elantkowska, J. 1961: Uzbrojenie ludności kultury przeworskiej w okresie rzymskim na Śląsku. Zeszyty Naukowe Uniwersytetu im. Adama Mickiewicza - Archeologia, Etnografia 2, 51-157.

Franz, L. 1932: Aus einer Bribatsammlung. Sudeta VIII, 39-41.

Godłowski, K. 1960: Studia nad stosunkami społecznymi w okresach późnolateńskim i rzymskim $w$ dorzeczu Odry $i$ Wisty. Próba interpretacji cmentarzysk. Warszawa, Wroclaw: Zaklad Narodowy im. Ossolinskich.

Godłowski, K. 1969: Kultura przeworska na Górnym Śląsku. Katowice, Kraków: Państwowe Wydawnictwo Naukowe, Kraków.

Godłowski, K. 1972: Badania na cmentarzysku z okresu rzymskiego w Kryspinowie, pow. Kraków. Sprawozdania Archeologiczne XXIV, 129-148.

Godłowski, K. 1976a: Das Gräberfeld in Kryspinów bei Kraków und seine Bedeutung für den Übergang zwischen der Latène- und der römischen Kaiserzeit in Kleinpolen. In: B. Chropovský (Hrsg.): Symposium. Ausklang der La Tène-Zivilisation und Anfänge der germanischen Besiedlung im mittleren Donaugebiet. Bratislava: VEDA, Publishing House of the Slovak Academy of Sciences, 59-80.

Godłowski, K. 1976b: Kryspinów district of Kraków (A cemetery from the late La Tène and the Roman period). Recherches Archeologiques de 1974, 32-43.

Godlowski, K. 1985: Przemiany kulturowe $i$ osadnicze $w$ potudniowej $i$ środkowej Polsce w mtodszym okresie przedrzymskim $i w$ okresie rzymskim. Wrocław: Zakład Narodowy im. Ossolińskich.

Godłowski, K. 1992: Zmiany w uzbrojeniu ludności kultury przeworskiej w okresie wpływów rzymskich. In: M. Głosek (red.): Arma et Ollae. Studia dedykowane Profesorowi Andrzejowi Nadolskiemu $w 70$ rocznice urodzin $i 45$ rocznice pracy naukowej. Sesja naukowa, Łódź, 7-8 maja 1992 r. Łódź: Stowarzyszenie Naukowe Archeologów Polskich, 71-88.

Godłowski, K. 1994: Die Chronologie der germanischen Waffengräber in der jüngeren und späten Kaiserzeit. In: C. von Carnap-Bornheim (Hrsg.): Beiträge zu römischer und barbarischer Bewaffnung in der ersten vier nachchristlichen Jahrhunderten. Akten des 2. Internationalen Kolloquiums in Marburg a. d. Lahn, 20. bis 24. Februar 1994. Lublin, Marburg: Wydawnictwo Uniwersytetu Marii Curie-Skłodowskiej, Vorgeschichtliches Seminar der Philipps-Universität, 169-178.

Godłowski, K., Mączyńska, M. 1972: Kryspinów district of Kraków. A cemetery of the Late La Tène and Roman periods. Recherches Archéologiques de 1971, 31-37.

Godłowski, K., Szadkowska, L. 1972: Cmentarzysko z okresu rzymskiego w Tarnowie, powiat Opole. Opolski Rocznik Muzealny V(2), 5-246. 
Godłowski, K., Wichman, T. 1998: Chmielów Piaskowy. Ein Gräberfeld der Przeworsk-Kultur im Świętokrzyskie-Gebirge. Monumenta archaeologica barbarica VI. Kraków: Secesja.

Gojda, M. 1984: K problematice hrobů s výzbroji na středoeuropských pohřebištích doby římské. Archeologické rozhledy XXXVI(1), 67-89.

Gruba, J., Ślusarski, Z. 1966: Bogato wyposażony grób z III wieku z Podlodowa w pow. tomaszowskolubelskim. Przegląd Archeologiczny XVII, 202-207.

Grzymkowski, A. 1986: Wstępne wyniki badań na birytualnym cmentarzysku ciałopalnym i szkieletowym z okresu rzymskiego w Modle, gm. Wiśniewo, woj. Ciechanowskie. Sprawozdania Archeologiczne XXXVIII, 222-260.

Grzymkowski, A. 1996: Ziemia Zawkrzeńska w pierwszych wiekach naszej ery. In: J. Antoniewicz (red.): Studia i Materiaty do Dziejów Ziemi Zawkrzeńskiej II. Warszawa: Państwowe Wydawnictwo Naukowe, 152-208.

Hedeager, L., Kristiansen, K. 1981: Bendstrup - en fyrstegrav fra den romerske jernalder, dens sociale og historiske miljø. Kuml 30, 81-149.

Jahn, M. 1921: Der Reitersporn, seine Entstehung und früheste Entwicklung. Mannus Biblothek 21. Leipzig: C. Kablitzsch.

Jamka, R. 1935: Cmentarzysko w Kopkach (pow. niski) na tle okresu rzymskiego w Małopolsce Zachodniej. Przegląd Archeologiczny V, 23-62.

Jamka, R. 1967: Materiały grobowe kultury przeworskiej z Bolesławia, pow. Dąbrowa Tarnowska. Materiaty Archeologiczne VIII, 193-196.

Janiczak, H. 1990: Kurhany kultury przeworskiej. Przegląd Archeologiczny 37, 121-155.

Jaskanis, J. 2005: Krupice. Ein Gräberfeld der Przeworsk- und Wielbark-Kultur in Ostpolen. Monumenta archaeologica barbarica X. Warszawa: Państwowe Muzeum Archeologiczne.

Jasnosz, S. 1952: Cmentarzysko z okresu późno-lateńskiego i rzymskiego w Wymysłowie, pow. Gostyń. Fontes Archaeologici Posnanienses 2 (1951), 2-284.

Kaczanowski, P. 1972: Drochlin, District od Włoszczowa, site 1. A Cemetery of the Roman Period and a Settlement of the Lausatian Culture. Recherches Archéologiques de 1971, 20-26.

Kaczanowski, P. 1976: Die Bewaffnung der Bevölkerung der Przeworsk-Kultur in der römischen Kaiserzeit und frühen Völkerwanderungszeit. Recherches Archeologiques de 1975, 81-85.

Kaczanowski, P., Kozłowski, J. K. 1998: Wielka Historia Polski 1. Najdawniejsze dzieje ziem polskich (do VII w.). Kraków: Bertelsmann Media.

Kaczmarek, I. 1962: Cmentarzysko z okresu wpływów rzymskich w Kotli, pow. Głogów. Silesia Antiqua IV, 213-239.

Kaletyn, T. 1963: Sprawozdanie z ratowniczych badań wykopaliskowych na osadzie kultury łużyckiej w Dębnicy pow. Trzebnica. Śląskie Sprawozdania Archeologiczne VI, 53-58.

Karpińska, A. 1926: Kurhany z okresu rzymskiego w Polsce ze szczególnem uwaględnieniem typu siedlemińskiego. Poznań: Poznańskie Towarzystwo Przyjaciół Nauk.

Kaszewska, E. 1973: Niektóre importy z wczesnego okresu rzymskiego między Prosną a Pilicą. Prace $i$ Materiaty Muzeum Archeologicznego $i$ Etnograficznego $w$ Lodzi, Seria Archeologiczna 20, 39-80.

Kaszewska, E. 1975: Wielookresowe cmentarzysko ciałopalne w Zadowicach, pow. Kalisz. Sprawozdania Archeologiczne XXVII, 141-164.

Kaszewska, E., Krause, E., Makiewicz, T., Ząbkiewicz-Koszańska, H. A. 1974: La Tène III - Période Romaine Civilisation de Przeworsk. Inventaria Archaeologica. Pologne XXXII, Fascicule Pl 201-205. Warszawa: Państwowe Wydawnictwo Naukowe.

Kempisty, A. 1965: Obrządek pogrzebowy w okresie rzymskim na Mazowszu. Światowit XXVI. Warszawa: Uniwersytet Warszawski.

Kietlińska, A. 1963: Struktura społeczna ludności kultury przeworskiej. Materiaty Starożytne IX, 7-97.
Kietlińska, A. 1974: Unikatowa płytka żelazna i inne zabytki z cmentarzyska kurhanowego w Lisowie, pow. Grójec. Wiadomości Archeologiczne XXXIX(1), 55-61.

Kietlińska, A., Dąbrowska, T. 1963: Cmentarzysko z okresu wpływów rzymskich we wsi Spycimierz, powiat Turek. Materiaty Starożytne IX, $143-254$.

Kobal', I. V. 1997: Kultura przeworska na Ukrainie Zakarpackiej. Wiadomości Archeologiczne LIII(2) (1993-1994), 31-62.

Kočka, W. 1939: Grób ciałopalny ze starszego okresu rzymskiego w Żerkowie, w pow. Jarocińskim. Wiadomości Archeologiczne XVI, 170-178.

Kokowski, A. 1991: Lubelszczyzna $w$ mtodszym okresie przedrzymskim $i$ w okresie rzymskim. Lublin: Wydawnictwo Uniwersytetu Marii Curie-Skłodowskiej.

Kokowski, A., Ścibior, J. 1990: Tombe princière de Sandomierz-Krakówka période romaine précoce. Inventaria Archaeologica. Pologne LXIII, Fascicule P1 385. Warszawa: Panstwowe wydawnictwo naukowe.

Kolendo, J. 1997: Central Europe and the Mediterranean World in the 1st-5th centuries A.D. In: P. Urbańczyk (ed.): Origins of Central Europe. Warszawa: Scientific Society of Polish Archaeologists, 5-21.

Kontny, B. 2001: Wojna oczami archeologa. Uwagi na temat sposobów walki ludności kultury przeworskiej w okresie wpływów rzymskich w świetle źródeł archeologicznych. Światowit III (XLIV), fasc. B, 91-119, Pl. 11-12.

Kontny, B. 2002: Broń jako wyraz zmian w obrządku pogrzebowym. Analiza zestawów uzbrojenia w kulturze przeworskiej od młodszego okresu wpływów rzymskich do początków okresu wędrówek ludów. Światowit IV (XLV), fasc. B, 101-144.

Kontny, B. 2003a: Przekaz z zaświatów. Analiza zestawów uzbrojenia z grobów w kulturze przeworskiej z okresu wczesnorzymskiego i początków młodszego okresu rzymskiego. Światowit V (XLVI), fasc. B, 111-178, Pl. 41-44.

Kontny, B. 2003b: Diversification of Burials with Weapons in the Przeworsk Culture in the Late Pre-Roman Period. In: C. von Carnap-Borheim (Hrsg.): Die Bewaffnung der Germanen und ihren Nachbarn in den letzten Jahrhunderten vor Christi Geburt. Lublin: Wydawnictwo Uniwersytetu Marii Curie-Skłodowskiej, 59-80.

Kontny, B. 2006: Ludzie z żelaza. Wojownicy z okresu wpływów rzymskich na ziemiach Polski. Z Otchtani Wieków 61(1-2), 54-70.

Kordowska, M., Kowalska, K. 2018: Łęgonice Mate, stan. II. Cmentarzysko kultury przeworskiej nad dolna Pilica. Monumenta archaeologica barbarica. Series Gemina VII. Warszawa: Państwowe Muzeum Archeologiczne w Warszawie.

Kostrzewski, B. 1939: Cmentarzysko z późnego okresu rzymskiego w Zaspach w pow. Tureckim. Przegląd Archeologiczny VI(2-3), 293-302.

Kostrzewski, B. 1947: Cmentarzysko z okresu rzymskiego w Koninie (woj. poznańskie). Przegląd Archeologiczny VII(2), 192-294.

Kostrzewski, B. 1954: Cmentarzysko z okresu późnolateńskiego i rzymskiego w Domaradzicach pow. Rawicz. Fontes Archaeologici Posnanienses IV (1953), 153-274.

Kostrzewski, J. 1923: Wielkopolska $w$ czasach przedhistorycznych. Poznań: Wydawnictwo Marjana Niemierkiewicza.

Kozak, D. N. 1984: Psevorska kul'tura u verchnomu Podnistrov'i i zachtdnomu Pobuz'i. Kiiv: Naukova dumka.

Kozak, D. N. 1985: Mogil'nik pshevors'koi kul'turi poblizu s. Griniv na Verchn'omu Podnistrov'i. Arkheologiya 52, 52-64.

Kozłowska, R. 1972: Cmentarzysko z okresów późnolateńskiego i wpływów rzymskich w Wesółkach, pow. Kalisz (stan. 5). Sprawozdania Archeologiczne XXIV, 349-390.

Kropotkin, V. V. 1977: Denkmäler der Przeworsk-Kultur in der Westukraine und ihre Beziehungen zur Lipica- und Černjachov-Kultur. In: B. Chropovsky (Hrsg.): Symposium. Ausklang der 
Latène-Zivilisation und Anfänge der germanischen Besiedlung im mittleren Donaugebiet. Bratislava: VEDA, Publishing House of the Slovak Academy of Sciences, 173-200.

Lepówna, B. 1956: Cmentarzysko z młodszego okresu rzymskiego w Miksztalu, pow. Kutno. In: K. Jażdżewski (red.): Na dziesięciolecie tódzkiego ośrodka archeologicznego. Acta Archaeologica Universitatis Lodziensis 4. Łódź: Zakład im. Ossolińskich, 43-51.

Liana, T. 1976: Kurhan i cmentarzysko kultury przeworskiej na stan. II w Łęgonicach Małych, pow. Opoczno. Wiadomości Archeologiczne XLI(1), 64-127.

Machajewski, H. 1980: Kultura wielbarska a kultura przeworska w Wielkopolsce. Fontes Archaeologici Posnanienses XXIX (1978), 49-64.

Madyda-Legutko, R., Rodzińska-Nowak J., Zagórska-Telega J. 2011: Opatów, Fpl. 1, Ein Gräberfeld der Przeworsk-Kultur im nordwestlichen Kleinpolen. Katalog. Tafeln. Monumenta archaeologica barbarica XV. Warszawa, Kraków: Fundacja Monumenta Archaeologica Barbarica, Państwowe Muzeum Archeologiczne w Warszawie; Instytut Archeologii Uniwersytetu Jagiellońskiego.

Makiewicz, T. 1970: Cmentarzysko z okresu rzymskiego w Białej, pow. Łódź. Prace $i$ Materiaty Muzeum Archeologicznego $i$ Etnograficznego $w$ Łodzi, Seria Archeologiczna 17, 175-255.

Martyniak, G., Pastwiński, R., Pazda, S. 1997: Cmentarzysko kultury przeworskiej w Ciecierzynie, gmina Byczyna, woj. Opolskie. Wrocław: Oficyna wydawnicza Sudety.

Mączyńska, M. 1971: Cmentarzysko i osada z okresu rzymskiego w Krapkowicach. Materiaty Starożytne $i$ Wczesnośredniowieczne I, 251-316.

Mączyńska, M. 2003: Przeworsk-Kultur. Jüngere und späte Römische Kaiserzeit. In: J. Hoops: Reallexikon der Germanischen Altertumskunde 23. Pfalzel-Quaden. Zweite, völlig neu bearbeitete und stark erweiterte Auflage. Berlin: Walter de Gruyter, 553-567.

Mączyńska, M., Rudnicka, D. 2004: Ein Grab mit römischen Importen aus Czarnówko, Kr. Lebork (Pommern). Germania 82(2), 397-429.

Moszczyński, J. 1994: Cmentarzyska kultury przeworskiej z okresu rzymskiego w Kutnie woj. płockie (stan. 2, 3, 6). In: J. Gruba, A. Kokowski (red.): Kultura Przeworska I. Lublin: Wydawnictwo Uniwersytetu Marii Curie-Skłodowskiej, 213-236.

Moszczyński, J. 1996: Groby z wczesnego okresu wpływów rzymskich na cmentarzysku kultury przeworskiej w Kutnie, stan. 6, woj. płockie (sezon 1993 r.). Łódzkie Sprawozdania Archeologiczne II, 87-99.

Okulicz, J. 1983: Cmentarzyska z okresu rzymskiego na „Łysej Górze” i „Zwierzyńcu” w Gródkach w województwie ciechanowskim. Rocznik Olsztyński XIV/XV, 73-189.

Olędzki, M. 1994: Uzbrojenie z cmentarzyska kultury przeworskiej w Wólce Domaniowskiej koło Radomia. Łódzkie Sprawozdania Archeologiczne I, 107-118.

Olędzki, M., Teske, G. 1987: Nowe materiały kultury przeworskiej z cmentarzyska w miejscowości Kurza woj. Kaliskie. Wiadomości Archeologiczne XLVIII(1) (1983), 77-91.

Osiński, K. 1923: Wykopalisko w Budach Łańcuckich z epoki młodszego okresu Cesarstwa Rzymskiego. Rocznik Towarzystwa Przyjaciól Nauk w Przemyślu 3 (1913-1922), 1-32.

Peiser, F. E. 1916: Das Gräberfeld von Pajki bei Prassnitz in Polen. Königsberg: Grafe \& Unzer.

Pescheck, Ch. 1936: Zwei neue Germanenfunde aus dem Kreise Glogau. Altschlesische Blätter 11, 185-188.

Pescheck, Ch. 1939: Die frühwandalische Kultur in Mittelschlesien (100 vor bis 200 nach Chr.). Leipzig: C. Kabitzsch.

Peschel, K. 1991: Zur Chronologie und Struktur des elbgermanischen Gräberfeldes Großromstedt. In: F. Horst, H. Keiling (Hrsg.): Bestattungswesen und Totenkult in ur- und frühgeschichtlicher Zeit. Berlin: Akademie-Verlag, 131-155.
Petersen, E. 1934: Neue wandalische Grabfunde aus dem 2.-4. Jahr. n. Chr. Altschlesien 4, 139-161.

Pfutzenreiter, F. 1929: Das wandalische Brandgräbefeld aus der römischen Kaiserzeit bei Stroppen Kr. Guhrau. Altschlesien 2, 250-273.

Pieczyński, Z. 1967: Cmentarzysko z okresu wędrówek ludów i z wczesnego średniowiecza z Konina. Fontes Archaeologici Posnanienses XVIII (1967), 54-67.

Piętka-Dąbrowska, T. 1960: Cmentarzysko z okresu rzymskiego w miejscowości Domaradzyn pow. Łowicz. Wiadomości Archeologiczne XXVI(3-4) (1959-1960), 225-230.

Radig, W. 1942: Das ostgermanische Gräberfeld von Stara Wies, Kreis Sokolow. Die Burg 3, 179-224.

Rycel, G. 1983: Cmentarzysko kultury przeworskiej w Sobótce (st. 1), woj. Konińskie. Prace i Materiaty Muzeum Archeologicznego $i$ Etnograficznego w Łodzi, Seria Archeologiczna 28 (1981), 249-272.

Schultze, E. 1991: Waffenteile als Grabbeigaben in der römischen Kaiserzeit. In: F. Horst, H. Keiling (Hrsg.): Bestattungswesen und Totenkult in ur- und frühgeschichtlicher Zeit. Berlin: Akademie-Verlag, 177-186.

Siciński, W. 1988: Cmentarzysko kultury przeworskiej na stanowisku 1 we Wrzasku-Zagłobie, województwo łódzkie. Prace $i$ Materiaty Muzeum Archeologicznego $i$ Etnograficznego w Łodzi, Seria Archeologiczna 33 (1986), 261-271.

Skowron, J. 1997: Cmentarzysko kultury przeworskiej z późnego okresu wpływów rzymskich w miejscowości Piaski, gm. Kleszczów, woj piotrkowskie - st. 1. Prace i Materiaty Muzeum Miasta Zgierza II, 11-154.

Skurczyński, S. 1947: Archeolog na probostwie. Pamiętnik Kielecki 1947, 9-40.

Śmiszko, M. 1932: Kultury wczesnego okresu epoki cesarstwa rzymskiego w Matopolsce Wschodniej. Lwów: Lwowskie Towarzystwo Naukowe.

Smólka-Antkowiak, E., Ciesielski, Ł. 2019: Uwagi na temat dyspersji ostróg w przestrzeni cmentarzysk kultury przeworskiej. In: K. Kot-Legieć, A. Michałowski, M. Olędzki, M. Piotrowska (red.): Kultura przeworska. Procesy przemian i kontakty zewnętrzne. Łódź: Wydawnictwo Uniwersytetu Łódzkiego, 569-588.

Svešnikov, I. K. 1957: Mogil'niki lipickoi kul'tury v L'vovskoi oblasti (Raskopki u ss. Zvenigorod i Bolotnoe). Kratkie Soobsheniya Instituta Istorii Material'noj Kul'tury Akademii Nauk SSSR 68, 63-74.

Szarek-Waszkowska, E. 1971: Cmentarzysko kultury przeworskiej w miejscowości Opoka, pow. Puławy. Studia $i$ Materiaty Lubelskie 5, 79-186.

Szembekówna, J. 1902: Sprawozdanie z poszukiwań archeologicznych odbytych ostatniemi latami w Siemianicach (powiat kępiński). Roczniki Towarzystwa Przyjaciól Nauk Poznańskiego XXIX, 53-77.

Szembekówna, Z. 1905: Sprawozdanie z poszukiwań archeologicznych w Siemianicach (powiat kępiński) odbytych w latach 1902 i 1903. Roczniki Towarzystwa Przyjaciót Nauk Poznańskiego XXXI, 135-153.

Szembekówna, Z. 1909a: Sprawozdanie z poszukiwań archeologicznych w Siemianicach (powiat kępiński) odbytych w r. 1904. Roczniki Towarzystwa Przyjaciót Nauk Poznańskiego XXXV, 337-365.

Szembekówna, Z. 1909b: Dalszy ciag (za lata 1907 i 1908) opisu wykopalisk z cmentarzyska epoki rzymskiej $w$ Siemianicach, Siemianice. Unpublished report, Folder 903. Stored in: archive of the Muzeum Archeologiczne w Poznaniu.

Szmit, Z. 1921: Groby z okresu lateńskiego i rzymskiego na cmentarzysku „Kozarówka” w Drohiczynie nad Bugiem. Wiadomości Archeologiczne VI, 61-70.

Szydłowski, J. 1964: Cmentarzysko z okresu wplywów rzymskich w Choruli, pow. Krapkowice. Wroclaw: Zakład Narodowy im. Ossolińskich.

Szydłowski, J. 1974: Trzy cmentarzyska typu dobrodzieńskiego. Rocznik Muzeum Górnośląskiego. Archeologia 11. Bytom: Muzeum Górnośląskie. 
Szydłowski, J. 1977: Grupa dobrodzieńska jako wyraz lokalnych przemian w schytkowej fazie kultury przeworskiej. Katowice: Uniwersytet Śląski.

Tackenberg, K. 1925: Die Wandalen in Niederschlesien. Berlin: De Gruyter.

Tejral, J. 2002: Die Sporen. In: J. Peška, J. Tejral (Hrsg.): Das germanische Königsgrab von Mušov in Mähren. Teil 2. Text. Monographien 55. Mainz: Verlag des Römisch-Germanischen Zentralmuseums, 141-188.

Wilkoński, L. 1938: Grób ciałopalny z okresu wczesnorzymskiego z Krakówki pod Sandomierzem. Wiadomości Archeologiczne XV, 106-125

Weski, T. 1982: Waffen in germanischen Gräbern der älteren römischen Kaiserzeit südlich der Ostsee. BAR International Series 147. Oxford: B.A.R.

Ząbkiewicz-Koszańska, H. A. 1966-1967: Cmentarzysko kultury przeworskiej w Walichnowych, pow. Wieruszów, stanowisko 2. Wiadomości Archeologiczne XXXII(3-4), 548-551.

Ząbkiewicz-Koszańska, H. A. 1973: Grób wojownika kultury przeworskiej z Ochędzyna Nowego, pow. Wieruszów. Prace $i$ Materiaty Muzeum Archeologicznego i Etnograficznego w Łodzi, Seria Archeologiczna 20, 111-128.

Zagórska-Telega, J. 2000: Bogaty pochówek kobiecy na cmentarzysku kultury przeworskiej w Opatowie, stan. 1, woj. Śląskie. In: R. Madyda-Legutko, T. Bochnak (red.): Superiores Barbari. Księga pamiątkowa ku czci Profesora Kazimierza Godtowskiego. Kraków: Uniwersytet Jagielloński, 313-326.

Zielonka, B. 1951: Groby ludności kultury przeworskiej w Lachmirowicach, pow. Inowrocław. Z Otchtani Wieków XX(7-8), 120-128.

Zielonka, B. 1953a: Adolfin, gm. Sędzin, pow. Aleksandrów Kujawski. Z Otchtani Wieków XXII(5), 187-188.

Zielonka, B. 1953b: Cmentarzysko z okresu cesarstwa rzymskiego w Lachmirowicach w pow. inowrocławskim. Przegląd Archeologiczny IX(2-3), 353-386.

Zielonka, B. 1958: Cmentarzysko w Bodzanowie w pow. aleksandrowskim. Przegląd Archeologiczny X, 331-382.

Zielonka, B. 1961a: Stanowisko wielokulturowe w Adolfinie w pow. aleksandrowskim. Przegląd Archeologiczny XIII, 197-204.

Zielonka, B. 1961b: Końcowe sprawozdanie z badań w Bodzanowie w pow. Aleksandrowskim. Przegląd Archeologiczny XIII, 190-196.

Zielonka, B. 1970: Rejon Gopła w okresie późnolateńskim i rzymskim. Fontes Archaeologici Posnanienses XX (1969), 147-218.

Ziemlińska-Odojowa, W. 1999: Niedanowo. Ein Gräberfeld der Przeworsk- und Wielbark-Kultur in Nordmasowien. Monumenta archaeologica barbarica VII. Kraków: Secesja.

\section{Resumé}

Hroby s ostruhami z oblasti silně militarizované przeworské kultury bývají interpretovány jako pohřby bojovníků na koních (jezdci). Tomu však odporuje jednak skutečnost, že v inventáři některých z nich nejsou žádné zbraně, jednak stále častější antropologické analýzy, dokazující že se často jedná o pohřby žen nebo dětí. Většina hrobů však soubory zbraní obsahuje, což vskutku naznačuje, že se jedná o bojovnické pohřby. Předmětem této studie je poukázat na rozmanitost výzbroje v hrobech s ostruhami. Autorka se zabývá tím, do jaké míry se výzbroj bojovníka na koni liší od výzbroje pěšího bojovníka a jak různorodá je výzbroj uvnitř skupiny bojovníků na koních. Výzkum byl prováděn $\mathrm{s}$ přihlédnutím $\mathrm{k}$ několika faktorům - doba, velikost pohřebiště a na něm doložený počet „pohřbů jezdcư“a odlišnost každé komunity, což dosvědčují zkoumané nekropole.
Analýza provedená v tomto článku poukázala na významné rozdíly týkající se především bohatství výzbroje jezdců ve vztahu k pěším bojovníkům, čímž potvrdila tezi o vysokém majetkovém a sociálním postavení pohřbených jedinců s ostruhami. Zemřelí jezdci měli také význačné postavení ve vojenské struktuře, a dá se tudíž předpokládat, že vojenští velitelé (náčelníci) figurovali právě mezi jezdci na koních. Na to mimo jiné ukazuje analýza zbraní ojedinělých bojovníků na koních pohřbených mezi menšími komunitami. V takových případech byly hroby nejčastěji vybaveny nejbohatšími soubory zbraní, včetně mečů. Mezi jezdci pohřbenými ve větší skupině na pohřebišti je vidět stále bohaté, ale rozmanitější soubory zbraní, které mohou u jízdy naznačovat rozdělení na velitele a válečníky nižšího postavení.

Zde provedená analýza rovněž ukazuje, že ke změnám, které se odehrály ve výbavě jezdců, došlo určitým způsobem, a to bez ohledu na změny ve výzbroji pěších bojovníků. $V$ důsledku válek vedených na římské hranici (limitu) došlo k obohacování výzbroje hlavně jízdních bojovníků.

Stávající rozdíly ve stupni militarizace pohřbů s ostruhami byly podmíněny časem a prostorem. Na počátku letopočtu představovaly ostruhy především funkční artefakt - atribut bojovníka. Postupem doby získaly symbolický význam, který se projevuje výskytem ostruh $\mathrm{v}$ hrobech beze zbraní, často patřících ženám a dětem. Je třeba zdůraznit, že podíl hrobů se zbraněmi a bez nich se v jednotlivých komunitách lišil. Poslední část analýzy potvrdila, že pro některé skupiny lidí měla ostruha čistě vojenský charakter, zatímco pro jiné to byl častěji dar nebo symbol, jehož význam můžeme jen předpokládat.

\section{Contact}

\section{Emilia Smółka-Antkowiak}

Uniwersytet im. Adama Mickiewicza w Poznaniu

Wydzial Archeologii

ul. Uniwersytetu Poznańskiego 7

PL-61 614 Poznań

$\&$

Muzeum Archeologiczne w Poznaniu

ul. Wodna 27

PL-61 781 Poznań

emilia_smolka@wp.pl 